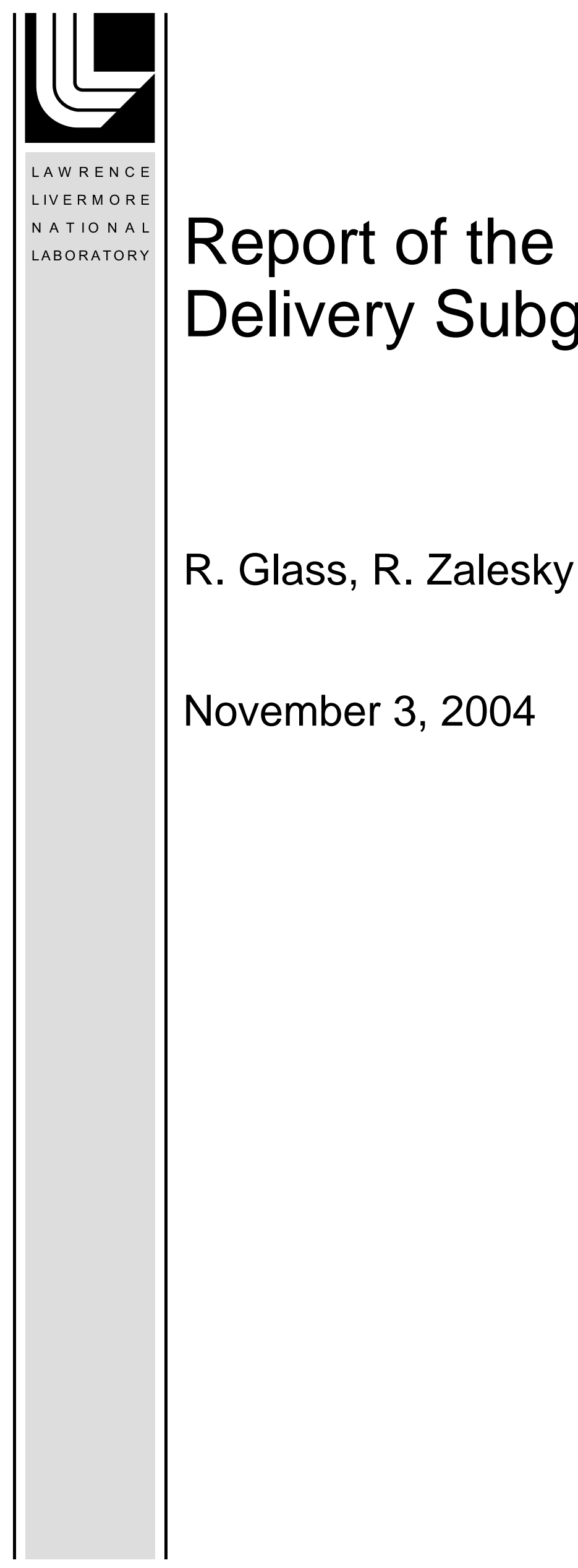

Report of the Production and Delivery Subgroup

R. Glass, R. Zalesky

November 3, 2004 
This document was prepared as an account of work sponsored by an agency of the United States Government. Neither the United States Government nor the University of California nor any of their employees, makes any warranty, express or implied, or assumes any legal liability or responsibility for the accuracy, completeness, or usefulness of any information, apparatus, product, or process disclosed, or represents that its use would not infringe privately owned rights. Reference herein to any specific commercial product, process, or service by trade name, trademark, manufacturer, or otherwise, does not necessarily constitute or imply its endorsement, recommendation, or favoring by the United States Government or the University of California. The views and opinions of authors expressed herein do not necessarily state or reflect those of the United States Government or the University of California, and shall not be used for advertising or product endorsement purposes.

This work was performed under the auspices of the U.S. Department of Energy by University of California, Lawrence Livermore National Laboratory under Contract W-7405-Eng-48. 


\section{Report of the Production and Delivery Subgroup}

Final Report, October 29, 2004

Team Members: Bob Glass and Rick Zalesky (Co-Leaders), Charles Powars, Suzanne Klein, Joan Ogden, Sandy Thomas, Craig Horne, Rob Friedland, Robert Wichert, Ben Ovshinsky, Mitchell Pratt, Tim Lipman, Doug Grandy, Dave McCarthy, David Tsay, Michele Davies,

Alan Mace, Steve Shaffer

\section{$\underline{\text { Introduction }}$}

The Production and Delivery Subgroup was tasked with evaluating the various options that could be used for hydrogen production and delivery in terms of availability/industry readiness, technical and economic barriers, and environmental considerations. Hydrogen can be produced using a variety of feedstocks and conversion technologies. The feedstock options include water, natural gas, coal, petroleum, methanol, ethanol, biomass, and organic waste streams. Ultimately, using these domestic resources we will be able to produce all the hydrogen we will need for the complete conversion of our transportation infrastructure. The various conversion technologies include electrolysis, reforming (principally of natural gas, but also ethanol and methanol), photobiological and photoelectrochemical, biofermentation, pyrolysis and gasification of biomass and coal, high temperature thermochemical, and catalytic membranes. All of these production technologies are being actively researched by DOE's Office of Hydrogen, Fuel Cells and Infrastructure Technologies (HFCIT); and other offices within DOE support work that complements the HFCIT Program activities. In addition, private industry is also dedicating significant resources to these efforts.

In establishing the California Hydrogen Highway Network (CA H2 Net) we must utilize both distributed (that is, hydrogen that is produced at the point of use) as well as centralized production of hydrogen. Because of technical and economic barriers, most of the technologies for hydrogen production listed above will not become practical for either mode of hydrogen production in large quantities until at least the 2015-2030 timeframe. In the near term, that is, the transitional period between now and 2010 when we will establish a widely available hydrogen fueling infrastructure in California, the distributed production options of reforming and electrolysis will play the dominant role. In addition, production of hydrogen at centralized plants using natural gas reforming and delivery of pressurized or liquefied hydrogen by truck will be utilized. This is a logical extension of the current merchant hydrogen market.

\section{Production Rollout Phases}

Three phases of hydrogen production technology rollout are considered: Phase I (now-2010), Phase II (2010-1015), and Phase III (post-2015). These phases are briefly described below. Following this, the various technologies that can be used for hydrogen production and delivery are described in more detail. We focus our discussion on Phase I activities and on the technologies that will have the greatest impact this timeframe. More detailed discussions for these technologies are provided that summarize availability/industry readiness, technical barriers, economic barriers, environmental considerations, and 2010 
projected cost for hydrogen. For technologies that will have a post-2015 impact, more qualitative descriptions are provided. In the interest of brevity, this discussion is not intended to be comprehensive. A bibliography is provided at the end of this section that will direct the interested reader to additional resources. Finally, we end this section with our recommendations for what resources will be needed to evolve the hydrogen production and delivery infrastructure.

Phase I

As discussed above, there are three technologies used for hydrogen production and delivery today: on-site electrolysis, on-site reforming, and centralized reforming with delivery by truck. Mobile refuelers are another potential hydrogen refueling option. Collectively, before the end of 2004 these technologies will be utilized in the establishment of nineteen refueling stations/sites in California that are used in a variety of automobile and bus demonstration projects. In addition, one demonstration project involving the delivery of hydrogen by an existing pipeline is scheduled for completion in Torrance in 2004. Several other projects are scheduled to come on-line in 2005. The location of these sites and the specific methodology employed are discussed by the Sites Subgroup. The total potential hydrogen generation capacity at the current sites is approximately $3800 \mathrm{~kg} /$ day, not including the planned hydrogen pipeline in Torrance (capacity TBD). At the various sites, hydrogen is supplied either as pressurized gas with pressures ranging from 2000-5000 psi, liquefied hydrogen, or as compressed natural gas $(\mathrm{CNG}) / \mathrm{H}_{2}$ blends. None of the sites are accessible to the general public. The chart that follows summarizes current production options. While it is still in much earlier demonstration phase than electrolysis or reforming, biomass gasification is one other technology that offers some promise for further development in Phase I. If it is further developed within this time period, this technology will only lend itself to centralized production, with truck delivery to refueling stations. It is included in the following chart for completeness. The current state of development and areas for further technology development are discussed more fully in the individual sections for the various technologies. The comments provided in the chart below are couched in terms of "if the hydrogen generated could be used for transportation uses in fuel cell vehicles (FCVs)/hydrogen internal combustion engine vehicles (H2ICEVs)." 
Status of Hydrogen Production and Delivery in 2004

\begin{tabular}{|c|c|c|c|c|c|}
\hline $\begin{array}{l}\text { Production/ } \\
\text { Delivery } \\
\text { Option }\end{array}$ & Availability & $\begin{array}{l}\text { Existing } \\
\text { capacity }\end{array}$ & $\begin{array}{l}\text { California } \\
\text { distribution }\end{array}$ & $\begin{array}{l}\text { Environmental } \\
\text { benefit }\end{array}$ & $\begin{array}{l}\text { Cost (relative } \\
\text { to gasoline) }\end{array}$ \\
\hline $\begin{array}{l}\text { Distributed } \\
\text { electrolysis } \\
\text { using grid } \\
\text { electricity }\end{array}$ & Yes & Very low & $\begin{array}{l}\text { Localized } \\
\text { (very few } \\
\text { demonstrations) } \\
\text { concentrated in } \\
\text { LA, SF areas and } \\
\text { Sacramento }\end{array}$ & $\begin{array}{l}\text { Reduced } \\
\text { pollutants, but } \\
\text { increased GHG } \\
\text { emissions }\end{array}$ & $\begin{array}{l}\text { Very high } \\
\text { (unless using } \\
\text { off-peak or } \\
\text { nuclear) }\end{array}$ \\
\hline $\begin{array}{l}\text { Distributed } \\
\text { electrolysis } \\
\text { using } \\
\text { renewables } \\
\text { (solar, wind) }\end{array}$ & Yes & Very low & $\begin{array}{l}\text { Localized (only } \\
\text { a couple of } \\
\text { demonstrations) }\end{array}$ & Zero emissions & $\begin{array}{l}\text { Very high } \\
\text { (wind } \\
\text { potentially } \\
\text { more } \\
\text { economical in } \\
\text { nearer term) }\end{array}$ \\
\hline $\begin{array}{l}\text { Distributed } \\
\text { reforming of } \\
\text { natural gas at } \\
\text { refueling site }\end{array}$ & Yes & Very low & $\begin{array}{l}\text { On site in } \\
\text { several small } \\
\text { demonstrations }\end{array}$ & $\begin{array}{l}\text { Reduced } \\
\text { pollutants; } \\
\text { hydrogen } \\
\text { produced from } \\
\text { NG reforming } \\
\text { and stored on- } \\
\text { board and used in } \\
\text { a FCV has } \\
\text { potential for } 41 \% \\
\text { reduced GHGs } \\
\text { relative to } \\
\text { gasoline ICEV. }\end{array}$ & High \\
\hline $\begin{array}{l}\text { Natural gas } \\
\text { reforming at } \\
\text { large central } \\
\text { facilities with } \\
\text { truck and } \\
\text { pipeline } \\
\text { delivery }\end{array}$ & Yes & High & $\begin{array}{l}\text { Concentrated at } \\
\text { refineries (SF } \\
\text { Bay, LA Basin) } \\
\text { and merchant } \\
\text { producers } \\
\text { (Sacramento, SF } \\
\text { Bay, LA Basin) }\end{array}$ & See above & $\begin{array}{l}\text { High (but less } \\
\text { than } \\
\text { distributed) }\end{array}$ \\
\hline $\begin{array}{l}\text { Centralized } \\
\text { biomass } \\
\text { gasification }\end{array}$ & Yes & Very low & $\begin{array}{l}\text { Early } \\
\text { demonstration at } \\
\text { a couple of sites }\end{array}$ & Carbon "neutral" & Very high \\
\hline
\end{tabular}

Utilizing technologies available today, DOE in collaboration with private industry has planned a number of additional demonstrations in California in Phase I. The refueling centers will be co-located with planned vehicle fleet demonstrations by the automobile manufacturers. The specific details of these demonstrations have yet to be made public. It is planned that these DOE/industry co-funded projects will result in an additional 19-22 refueling stations in the State. The current and planned refueling sites will be located in the 
Los Angeles, San Francisco Bay, and Sacramento regions. As is the case today, for distributed production, in the near term only electrolysis and reforming will be widely available. These technologies will be able to utilize the existing electrical grid and natural gas distribution systems in California, and this will allow the establishment of a hydrogen refueling infrastructure to be accomplished more quickly and efficiently. With accelerated development we envision distributed refueling stations that could produce hydrogen in the 50$250 \mathrm{~kg}$ /day range. In addition, centralized production (primarily at large reforming facilities, with some contribution from biomass gasification facilities, and perhaps at nuclear sites using off-peak electricity) and distribution of compressed or liquefied hydrogen by truck, rail, barges, and possibly to a limited extent through pipelines will also be available. In areas without natural gas service, distributed reforming of methanol or ethanol could be employed. These energy carriers could be derived from biomass sources. To say that these technologies will be available means that they exist today; that is, there are commercial suppliers of electrolyzers and reformers, and truck delivery of hydrogen, ethanol, and methanol is a wellestablished part of the existing merchant business in California. It does not imply that there are not technical, economic, logistical, safety/codes and standards issues, and environmental barriers in developing the transitional hydrogen refueling infrastructure. Importantly, in the early years it is unlikely that any method of providing hydrogen will be able to meet the stated DOE goal of $\$ 1.50 / \mathrm{kg}$ hydrogen at the pump by 2010 (we note that this cost goal is likely to be raised in the near future). This goal was set early on in order to provide the consumer with hydrogen at a cost comparable to gasoline (1 kg of hydrogen is approximately equivalent in energy content to one gallon of gasoline). For less mature technologies, DOE has set more modest cost goals for 2010 and 2015. Nevertheless, we believe that enough hydrogen can be produced using the three methods outlined above at a cost acceptable to many environmentally-conscious consumers and for fleet operators, especially if fuel cell vehicles can fulfill their promise of having much greater efficiencies than gasoline internal combustion engine vehicles, and if appropriate incentives can be applied. While the production and delivery options (other than biomass) for Phase I still result in greenhouse gas and other pollutant emissions (however, in most cases less than for gasoline ICEVs), it is hoped that they will nonetheless lead to the development of more sustainable hydrogen production methods.

\section{$\underline{\text { Phases II and III }}$}

In the long term, 2010-2050, other production technologies will come on-line as further research removes technical barriers and optimized engineering, lower cost materials and systems, mass production, and reduced operating and maintenance costs removes economic barriers. These advanced hydrogen production technologies include photobiological and photoelectrochemical, biofermentation, pyrolysis and gasification of biomass and coal, high temperature thermochemical, and catalytic membranes. Many of these technologies make use of renewable resources that have no greenhouse gas or pollutant emissions or are in principle carbon-neutral. It is our vision that by mid-century hydrogen can become the dominant energy carrier; production methods will be regionally dispersed, both centralized and distributed (although increasingly centralized with hydrogen pipelines). In the years beyond 2010 "carbon-free" or "carbon-neutral" production methods will become more and 
more utilized. In this regard, we note that some methods, such as reforming and coal gasification, could still be viable with $\mathrm{CO}_{2}$ sequestration.

\section{Production Options}

\section{Electrolysis}

\section{Technology Overview}

Electrolysis systems use electricity to split water into hydrogen and oxygen. This technology has been used for decades in industrial, military and space applications sometimes for the hydrogen value and sometimes for the oxygen value (i.e. life support). There are two types of conventional electrolyzers: alkaline and proton exchange membrane (PEM). One principle difference between the two is in the type of electrolyte they use.

Alkaline electrolyzers use an aqueous solution of potassium hydroxide $(\mathrm{KOH})$ as the electrolyte which has a very high conductivity. The electrolyzer sometimes resembles a tank and has electrodes connected in parallel. A membrane is placed between the cathode and anode, which separate the hydrogen and oxygen as the gases are produced, but allows the transfer of ions. A related design resembles a filter press and has electrolysis cells connected in series; hydrogen is produced on one side of the cell, oxygen on the other. Again, a membrane separates the electrodes. Alkaline electrolyzers typically operate in a balanced pressure mode such that pressure increases in the hydrogen gas also require increases in the oxygen gas unless mechanical compression is supplied on the gas stream. Typical systems can be pressurized electrochemically to around $125 \mathrm{psi}$; with system redesign and optimization it may be possible to attain higher pressures, perhaps 700 psi. To attain higher pressures external compression will be required.

PEM electrolyzers use a solid electrolyte similar to that used in PEM fuel cells. In this system the electrolyte is a solid ion conducting membrane as opposed to the aqueous solution in the alkaline electrolyzers. The PEM membrane also serves to separate the hydrogen and oxygen gasses, as oxygen is produced at the anode on one side of the membrane and hydrogen is produced on the opposite side of the membrane. PEM electrolyzers typically operate at differential pressures maintaining an ambient pressure on the oxygen side while capable of achieving pressures over 2000 psi on the hydrogen side.

Both types of electrolyzers interface very well with renewable technologies since they can easily follow the intermittent loads of a renewable resource. In addition, they can operate efficiently up and down the generation range, have virtually instant turn on capability, operate at low temperature and make very pure hydrogen easily suitable for use in a PEM fuel cell.

A third type of electrolysis system deserves mention: solid oxide steam electrolyzers (SOE). These systems are constructed from durable ceramic materials and metal alloys and operate the $700-1000{ }^{\circ} \mathrm{C}$ range. Because they operate at such high temperatures, the voltages required for water splitting are reduced. The lower electricity usage results in a lower cost for hydrogen produced. These types of electrolyzers can have appreciably higher efficiencies than 
the alkaline or PEM electrolyzers and can produce hydrogen at pressure. Various efforts have been directed towards the development of SOE in the past, particularly in Germany and in the U.S. However, they are still under laboratory development and it remains unclear whether they will be commercialized in the 2005-2010 timeframe.

\section{Availability}

Commercial PEM and alkaline electrolysis systems are generally available today in various output ranges from less then $1 \mathrm{~kg}$ per day to over $1000 \mathrm{~kg}$ per day. While the technology behind these systems is solid, much work is left to do to optimize the cost, efficiency, safety and simplicity of these systems before widespread distribution is economically feasible. In addition, since the various technologies generate hydrogen at different pressures, there is corresponding development required for compression, storage and dispensing of the gas for fueling at 5,000-10,000 psi. Again, the technology to provide this downstream gas handling exists today and is in use in various demonstration projects. However, it also needs to be optimized for widespread commercial use. Expectations are that by 2010 that if the demand is there suppliers will be able to "mass" produce electrolyzer systems in sizes up to $250 \mathrm{~kg} /$ day. While there are several improvements in materials and designs that are need to increase system efficiency and durability, the major barrier is in cost.

\section{Costs}

Several efforts are underway by electrolysis manufacturers to lower the cost of the systems and improve the efficiency. The DOE has a 2015 goal of $\$ 2.85$ per $\mathrm{kg}$ for hydrogen by electrolysis. The reality is that adequate development work is already in process or in the planning stages to meet the technical requirements behind these costs (e.g. system efficiency improvements, reduction in compression stages). However, the likely scenario is to have a system design in place such that a production volume of say 1000 stations per year would yield those types of costs. Since industry expects that the Hydrogen Highway plus other programs anticipated for that timeframe will fall well short of that type of volume, some increase in costs from those goals should be expected.

The cost of the electrolyzer is governed by only a few simple factors. The first is electricity consumption which relates to efficiency. Another is capital equipment cost. Today, the end-to-end system efficiencies (includes compression, storage and dispensing) according to DOE published reports is around $60 \%$. In California the average cost of commercial electricity is 11.15 cents per $\mathrm{kWh}$. For a $1050 \mathrm{~kg} /$ day "nth" plant assumption (meaning mass produced, which they are not), assuming installed capital costs of $\$ 798 / \mathrm{kW}$ and system energy requirement of $53.5 \mathrm{kWh} / \mathrm{kg}$, the cost of hydrogen production is $\$ 7.63 / \mathrm{kg}$. ${ }^{1}$ Projections are that this cost can be reduced significantly by 2010-2015 with reduction in capital equipment cost, operating and maintenance costs, improved system efficiency, and lower cost electricity (e.g., use of renewables and nuclear). For instance, if electricity were available at 3.5 cents per $\mathrm{kWh}$ the cost of hydrogen would be more like $\$ 3.50 / \mathrm{kg}$ (we note that in some areas in California, as well as in many parts of the country that electricity costs can achieve this cost

\footnotetext{
${ }^{1}$ Calculation courtesy of Johanna Ivy Levene, National Renewable Energy Laboratory
} 
range using off-peak power). ${ }^{2}$ A long-term DOE goal is to reduce the installed capital costs to $\$ 300 / \mathrm{kW}$.

A third factor is capital cost recovery, which is a factor of cost and utilization. There are many numbers being tossed about regarding the cost to install this type of system to get it ready to fuel vehicles. Without greatly accelerated vehicle deployment, in almost any scenario put forth on the number of cars expected versus the number of stations in the baseline plan, the utilization factor associated with these stations will be pretty low. This will considerably drive up the capital amortization over the output of hydrogen and substantially increase the cost per $\mathrm{kg}$. This will be equally true with any form of capital asset employed in the next ten years.

The challenge for electrolysis is to decrease the capital cost by more than $50 \%$, increase system efficiency, and decrease operating and maintenance costs. Electricity at high cost is a major economic roadblock. However, if renewable resources can be utilized with electricity costs of less than 4 cents per $\mathrm{kWh}$, then the cost of production of hydrogen can easily be brought down. If electricity from nuclear can be utilized, an economicallycompetitive pathway for hydrogen production is also attainable. No matter what the cost of electricity is, electrolysis will play a large part in the transition to a hydrogen economy in California simply because it is a proven, available technology that is scalable to sizes needed for distributed hydrogen production. It is versatile and easily adaptable to current and future sources of electricity and has a plentiful, entirely domestically-available feedstock (water). Perhaps no other technology can make as broad-sweeping claims.

\section{Environmental Considerations}

The simple fact when considering electrolysis for fueling is that you need electricity to make the hydrogen. If that electricity is generated by renewable technologies or nuclear then you have zero emissions. Conversely, if that electricity is generated all by coal fired power plants you have increased emissions. California's electricity supply is unique in North America in that a higher percentage of it is "carbon free" $(40-45 \%$ is provided by nuclear and renewables compared to $25 \%$ nationally) so this helps the overall energy/pollution question. California also has specific standards that will insure that any new electricity generation for use in the state would come from very clean and/or renewable resources. In any case, using electrolyzers to begin to develop the hydrogen infrastructure and continue the development of the technology is key both to the survival of the small companies making this equipment and also to achieve the breakthroughs required to allow the efficient marriage of this technology with renewable assets when and as they become more widespread and cost effective.

\footnotetext{
${ }^{2}$ Calculation courtesy Johanna Ivy Levene, National Renewable Energy Laboratory
} 


\begin{tabular}{|c|c|c|c|c|c|}
\hline Electrolysis Mode & $\begin{array}{l}\text { Development } \\
\text { Status/Industry } \\
\text { Readiness }\end{array}$ & $\begin{array}{l}\text { Technical } \\
\text { Barriers }\end{array}$ & Economic Barriers & $\begin{array}{l}\text { Environmental } \\
\text { Considerations }\end{array}$ & $\begin{array}{l}\text { Projected Cost in } \\
2010\end{array}$ \\
\hline $\begin{array}{l}\text { a) Distributed using } \\
\text { grid electricity }\end{array}$ & $\begin{array}{l}\text { Alkaline and PEM } \\
\text { electrolyzers are } \\
\text { commercialized. } \\
\text { Systems have been } \\
\text { built having hydrogen } \\
\text { production capacities } \\
\text { ranging from less } \\
\text { than } 1 \mathrm{~kg} / \text { day to } 2500 \\
\mathrm{~kg} / \text { day (upper end } \\
\text { alkaline). Major } \\
\text { North American } \\
\text { companies include } \\
\text { Proton, Stuart, } \\
\text { Teledyne, and } \\
\text { Hydrogenics. } \\
\text { Industry could gear } \\
\text { up to mass produce } \\
\text { units in } 25-250 \\
\text { kg/day capacity in } \\
2005-2010 \text { time } \\
\text { frame (ultimately } \\
1000-1500 \mathrm{~kg} / \text { day } \\
\text { stations are desired } \\
\text { but may not be } \\
\text { economical for some } \\
\text { time). }\end{array}$ & $\begin{array}{l}\text { System efficiency } \\
\text { (currently 60-65\%) } \\
\text { needs } \\
\text { improvement. } \\
\text { Eliminate need for } \\
\text { costly external } \\
\text { compression- } \\
\text { develop } \\
\text { electrochemical } \\
\text { compression or } \\
\text { higher pressure cell } \\
\text { stacks. Low cost, } \\
\text { higher } \\
\text { performance, and } \\
\text { more durable } \\
\text { materials needed, } \\
\text { especially for high } \\
\text { pressure operation. } \\
\text { Improved, } \\
\text { simplified cell } \\
\text { stack and balance- } \\
\text { of-plant designs } \\
\text { needed, especially } \\
\text { power electronics. } \\
\text { Improved } \\
\text { manufacturing } \\
\text { capability needed } \\
\text { (cost reduction, } \\
\text { DFMA). }\end{array}$ & $\begin{array}{l}\text { High cost of electricity } \\
\text { and high capital } \\
\text { equipment cost results } \\
\text { in hydrogen cost of } \$ 8 \text { - } \\
10 / \text { kg currently. Capital } \\
\text { equipment cost } \\
\text { (particularly cell stack) } \\
\text { must decrease at least } \\
50 \% \text {. Operating and } \\
\text { maintenance costs must } \\
\text { decrease. Low cost } \\
\text { electricity must be } \\
\text { utilized (e.g., off peak, } \\
\text { nuclear). }\end{array}$ & $\begin{array}{l}\text { Grid electricity mix } \\
\text { can increase } \\
\text { greenhouse gas } \\
\text { emissions in large } \\
\text { scale electrolysis. } \\
\text { California has } \\
\text { advantage in a } \\
\text { relatively "clean" } \\
\text { grid (one third } \\
\text { renewable; 40-45\% } \\
\text { "carbon-free" with } \\
\text { nuclear included } \\
\text { which compares to } \\
25 \% \text { U.S.-wide). } \\
\text { New generation } \\
\text { mix will even be } \\
\text { cleaner than the } \\
\text { current average } \\
\text { grid mix. } \\
\text { Decreased } \\
\text { particulate and } \\
\text { NOx emissions are } \\
\text { realized. }\end{array}$ & $\begin{array}{l}\$ 2.85 / \mathrm{kg} \text { is DOE } \\
\text { goal for } 2015 \text {. Cost } \\
\text { of hydrogen in } \\
2010 \text { likely in } \$ 3 \text { - } \\
4 / \mathrm{kg} \text { range. }\end{array}$ \\
\hline
\end{tabular}




\begin{tabular}{|c|c|c|c|c|c|}
\hline Electrolysis Mode & $\begin{array}{l}\text { Development } \\
\text { Status/Industry } \\
\text { Readiness }\end{array}$ & $\begin{array}{l}\text { Technical } \\
\text { Barriers }\end{array}$ & Economic Barriers & $\begin{array}{l}\text { Environmental } \\
\text { Considerations }\end{array}$ & $\begin{array}{l}\text { Projected Cost in } \\
2010\end{array}$ \\
\hline $\begin{array}{l}\text { b) Distributed using } \\
\text { renewable electricity }\end{array}$ & See above & $\begin{array}{l}\text { More efficient } \\
\text { integration of } \\
\text { electrolyzer with } \\
\text { renewable } \\
\text { electricity sources } \\
\text { is needed. } \\
\text { Intermittent power } \\
\text { creates inefficiency } \\
\text { and hydrogen } \\
\text { availability } \\
\text { problems. Overall } \\
\text { system efficiency } \\
\text { needs significant } \\
\text { improvement. }\end{array}$ & $\begin{array}{l}\text { High capital cost for } \\
\text { solar systems in } \\
\text { addition to high capital } \\
\text { cost of electrolyzer } \\
\text { yields hydrogen at } \\
\text { much greater cost than } \\
\$ 8-10 / \mathrm{kg} \text {. Cost depends } \\
\text { on if the renewable } \\
\text { asset is being used as a } \\
\text { primary source of } \\
\text { power or if it is mainly } \\
\text { feeding other loads. }\end{array}$ & $\begin{array}{l}\text { Zero environmental } \\
\text { emissions and } \\
\text { allows use of } \\
\text { excess renewable } \\
\text { power in times } \\
\text { where load is } \\
\text { below capacity and } \\
\text { excess is not being } \\
\text { dumped to the grid. }\end{array}$ & $\begin{array}{l}\text { Wind will likely be } \\
\text { the only } \\
\text { economically viable } \\
\text { option by } 2010 \text { with } \\
\text { wind electricity } \\
\text { hopefully costing } \\
\text { less than } \\
\$ 0.05 / \mathrm{kWh} \text {. With } \\
\text { production tax } \\
\text { credits allowing } \\
\text { wind to reach } \\
\$ 0.025-0.035 / \mathrm{kWh} \text {, } \\
\text { the cost of } \\
\text { hydrogen } \\
\text { production could be } \\
\text { less than } \$ 3 / \mathrm{kg} \text {. }\end{array}$ \\
\hline
\end{tabular}




\section{Reforming}

\section{Technology Overview}

Reformers generate hydrogen from hydrocarbon or alcohol fuels. The most common technologies are steam methane reforming (SMR), auto-thermal reforming (ATR) and partial oxidation (POX). SMR on a very large scale has been the most common production technology at refineries and central production plants for decades. The hydrogen from these facilities is often piped short distances in vast quantities or truck delivered in either compressed or liquid form. (See Delivered Hydrogen Section.)

The challenge for the developers of on-site reformer developers has been to adapt this tested large-scale SMR technology to a much smaller scale. On-site reforming takes advantage of the existing infrastructures for fuel delivery, such as natural gas or methanol, alleviating the need for truck delivery of hydrogen. Reformers consist of two systems, the hydrogen generating process (SMR, ATR or POX) and the purification and clean-up technology, generally pressure swing adsorption (PSA) or membranes. The high purity hydrogen generated by the reformer will then be compressed and stored at 5,000 to 10,000 psi for dispensing to the vehicles. At locations which are distant from large-scale, centralized hydrogen production facilities, on-site reformers may provide the lowest cost production of hydrogen.

While the most common feedstock for reformers is natural gas, reformer companies are also working to develop and commercialize technology for other fuels as well. These include other hydrocarbons such as LPG, diesel and gasoline, methanol and ethanol. Efforts are underway to develop ethanol reformers, so that renewables (i.e., ethanol and methanol from biomass) can be part of the emerging reforming portfolio. While the hydrocarbons have an existing infrastructure advantage, ethanol is becoming an increasingly common additive to gasoline. This growing ethanol delivery infrastructure can be leveraged for the renewable production of hydrogen through reforming. Methanol has the added advantage of both an existing liquid delivery infrastructure and the potential for renewable production. Since methanol is both a common chemical feedstock and a common consumer product (windshield washer fluid) and a common racing fuel, the existing liquid delivery infrastructure is in place throughout California. The ability to deliver liquid methanol or ethanol to areas where natural gas is not available makes them candidates for distributed reforming in areas without natural gas service at prices competitive with natural gas reforming.

These on-site hydrogen generators range in size from about $1 \mathrm{~kg}$, or gallon gasoline equivalent, per hour up to $20 \mathrm{~kg} /$ hour. Several equipment suppliers have standardized around 5 and $10 \mathrm{~kg} /$ hour sizes, which would serve populations of 200-500 light-duty fuel cell vehicles, or 100 to 250 internal combustion engine (ICE) vehicles.

\section{Availability}

Reformer technology is approaching commercialization with at least a dozen on-site reformers in demonstration throughout the world. Major North American providers of reforming technology for refueling station applications are HyRadix, H2Gen and Ztek. 
Reformer-based refueling stations can be found at SunLine Transit in Thousand Palms, CA, at Pacific Gas \& Electric in Auburn, CA and at the City of Las Vegas, NV. On-going challenges include cost reduction and improved reliability. 


\begin{tabular}{|c|c|c|c|c|c|c|}
\hline \multicolumn{2}{|c|}{ Production Mode } & $\begin{array}{l}\text { Development } \\
\text { Status/Industry } \\
\text { Readiness }\end{array}$ & $\begin{array}{l}\text { Technical } \\
\text { Barriers }\end{array}$ & $\begin{array}{l}\text { Economic } \\
\text { Barriers }\end{array}$ & $\begin{array}{l}\text { Environmental } \\
\text { Considerations }\end{array}$ & $\begin{array}{l}\text { Projected Cost in } \\
2010\end{array}$ \\
\hline $\begin{array}{l}\text { On-site } \\
\text { Reforming }\end{array}$ & $\begin{array}{l}\text { a) fossil } \\
\text { fuels }\end{array}$ & $\begin{array}{l}\text { Reformers are } \\
\text { approaching } \\
\text { commercialization. } \\
\text { Systems have been } \\
\text { built having } \\
\text { hydrogen } \\
\text { production } \\
\text { capacities ranging } \\
\text { from less than } 25 \\
\text { kg/day to } 400 \\
\text { kg/day. Active } \\
\text { North American } \\
\text { companies include } \\
\text { ChevronTexaco, } \\
\text { H2Gen, Harvest } \\
\text { Energy } \\
\text { Technology, } \\
\text { HyRadix, Plug } \\
\text { Power and Ztek. }\end{array}$ & $\begin{array}{l}\text { Cost } \\
\text { reduction and } \\
\text { reliability are } \\
\text { the primary } \\
\text { challenges. } \\
\text { System } \\
\text { efficiency } \\
\text { improvement } \\
\text { will } \\
\text { marginally } \\
\text { reduce } \\
\text { hydrogen } \\
\text { costs. Low } \\
\text { cost, higher } \\
\text { performance, } \\
\text { and more } \\
\text { durable } \\
\text { components } \\
\text { needed. } \\
\text { Improved } \\
\text { manufacturin } \\
\text { g capability } \\
\text { needed (cost } \\
\text { reduction, } \\
\text { DFMA }{ }^{3} \text { ). }\end{array}$ & $\begin{array}{l}\text { Capital } \\
\text { equipment cost } \\
\text { results in } \\
\text { hydrogen } \\
\text { production cost } \\
\text { of } \$ 3.50 \text { - } \$ 6 / \mathrm{kg} \\
\text { currently. Capital } \\
\text { equipment cost } \\
\text { must decrease for } \\
\text { the } \mathrm{H}_{2} \text { price to } \\
\text { decrease. } \\
\text { Operating and } \\
\text { maintenance } \\
\text { costs must } \\
\text { decrease. Final } \\
\text { hydrogen price is } \\
\text { sensitive to } \\
\text { feedstock price; } \\
\text { for example } \\
\text { natural gas } \\
\text { feedstock at } \\
\$ 7.30 / \mathrm{MBTU} \\
\text { (California } \\
\text { average industrial } \\
\text { price) contributes } \\
\$ 1.25 / \mathrm{kg} \text { to the } \\
\text { price of } \\
\text { hydrogen. }\end{array}$ & $\begin{array}{l}\text { The most common } \\
\text { fuel for reformers is } \\
\text { natural gas, or other } \\
\text { hydrocarbons such as } \\
\mathrm{LPG}^{4} \text {. } \\
\text { Reforming does } \\
\text { result in } \mathrm{CO}_{2} \\
\text { emissions, but } \mathrm{H}_{2} \\
\text { made from natural } \\
\text { gas will reduce } \mathrm{CO}_{2} \\
\text { emissions from } \mathrm{FCV} \\
\text { by } 45 \% \text { to } 50 \% \\
\text { compared to gasoline } \\
\text { used in conventional } \\
\text { cars. Particulate and } \\
\text { NOx emissions from } \\
\text { most reformers are } \\
\text { negligible. }\end{array}$ & $\begin{array}{l}\$ 1.50 / \mathrm{kg} \text { is DOE goal } \\
\text { for } 2015 \text {. Cost of } \\
\text { hydrogen in } 2010 \\
\text { likely in } \$ 2.25- \\
\$ 3.00 / \mathrm{kg} \text { range } \\
\text { depending on } \\
\text { reformer size, } \\
\text { feedstock costs, } \\
\text { station utilization and } \\
\text { the return on } \\
\text { investment required } \\
\text { by the station owner. }\end{array}$ \\
\hline
\end{tabular}

${ }^{3}$ DMFA refers to Design for Manufacture and Assembly; DFMA is a registered trademark of Boothroyd and Dewhurst.

${ }^{4}$ LPG refers to liquid petroleum gas which is primarily propane in North America, but is predominantly butane in other countries. 


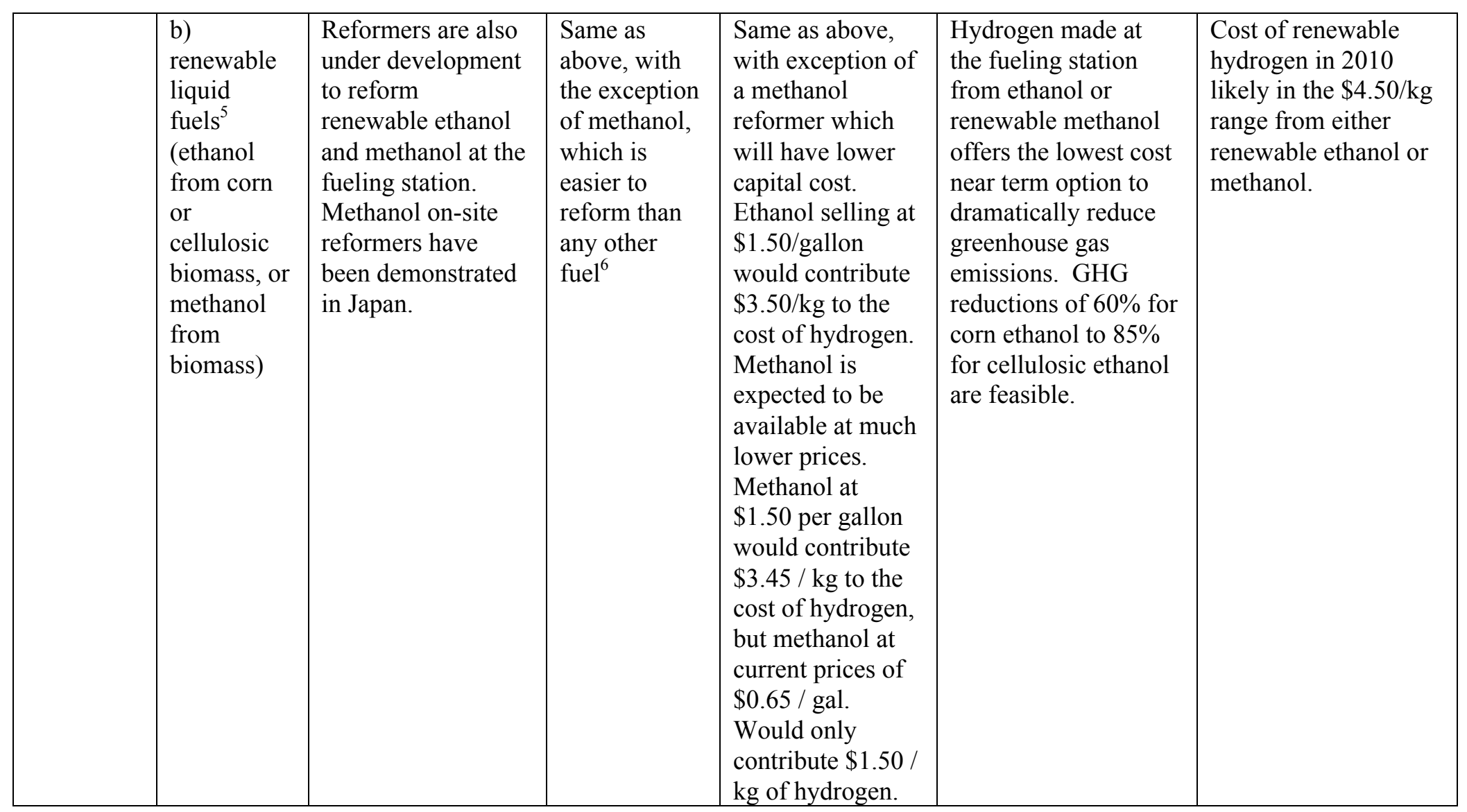

\footnotetext{
${ }^{5}$ This option excludes direct biomass gasification to produce hydrogen at a central facility, since that biomass-generated hydrogen would have to be transported to the fueling station, incurring added transportation costs.

${ }^{6}$ Methanol can be reformed at $260^{\circ} \mathrm{C}$, whereas all other fuels require temperatures above 600 to $800^{\circ} \mathrm{C}$ which adds to reformer cost and durability issues.
} 


\begin{tabular}{|c|c|c|c|c|c|c|}
\hline \multicolumn{2}{|c|}{ Production Mode } & \multirow{2}{*}{ 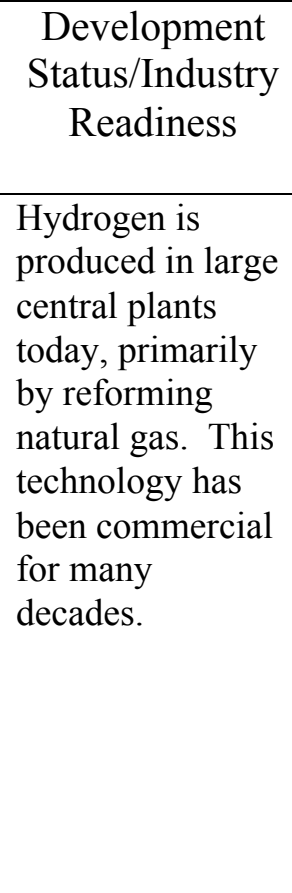 } & $\begin{array}{c}\text { Technical } \\
\text { Barriers }\end{array}$ & Economic Barriers & $\begin{array}{l}\text { Environmental } \\
\text { Considerations }\end{array}$ & $\begin{array}{c}\text { Projected Cost in } \\
2010\end{array}$ \\
\hline $\begin{array}{l}\text { Central } \\
\text { Plant } \\
\text { Production }\end{array}$ & $\begin{array}{l}\text { a) fossil } \\
\text { fuels - } \\
\text { liquid } \\
\text { delivery }\end{array}$ & & None & $\begin{array}{l}\text { The cost of liquefaction } \\
\text { of hydrogen }\left(20^{\circ} \mathrm{K} \text { or - }\right. \\
\left.253^{\circ} \mathrm{C}\right) \text { nearly doubles } \\
\text { the cost of production. } \\
\text { The fueling station } \\
\text { requires a heavily } \\
\text { insulated cryogenic } \\
\text { dewar to store the } \\
\text { liquid hydrogen, a } \\
\text { cryogenic liquid pump, } \\
\text { vaporizer, gaseous } \\
\text { storage tanks and } \\
\text { dispenser. Boil off } \\
\text { losses during transfer } \\
\text { and storage will add } \\
\text { cost. }\end{array}$ & $\begin{array}{l}\text { The electricity used to } \\
\text { liquefy hydrogen is } \\
\text { equivalent to } 30 \% \text { to } 35 \% \\
\text { of the lower heating value } \\
\text { of the hydrogen. The GHG } \\
\text { advantage of hydrogen- } \\
\text { powered FCVs is nearly } \\
\text { cancelled out by the GHGs } \\
\text { due to this extra electricity } \\
\text { requirement. }\end{array}$ & $\begin{array}{l}\text { The all-in costs of } \\
\text { delivered LH2 } \\
\text { including on-site } \\
\text { storage, vaporization } \\
\text { and dispensing will } \\
\text { depend on distance } \\
\text { to the LH2 plant, } \\
\text { size of the fueling } \\
\text { station, capital } \\
\text { recovery factors, etc. } \\
\text { For a mature station } \\
\text { costs are expected to } \\
\text { be in the } \$ 2.20 \text { to } \\
\$ 3.80 / \mathrm{kg} \text { range. }\end{array}$ \\
\hline
\end{tabular}




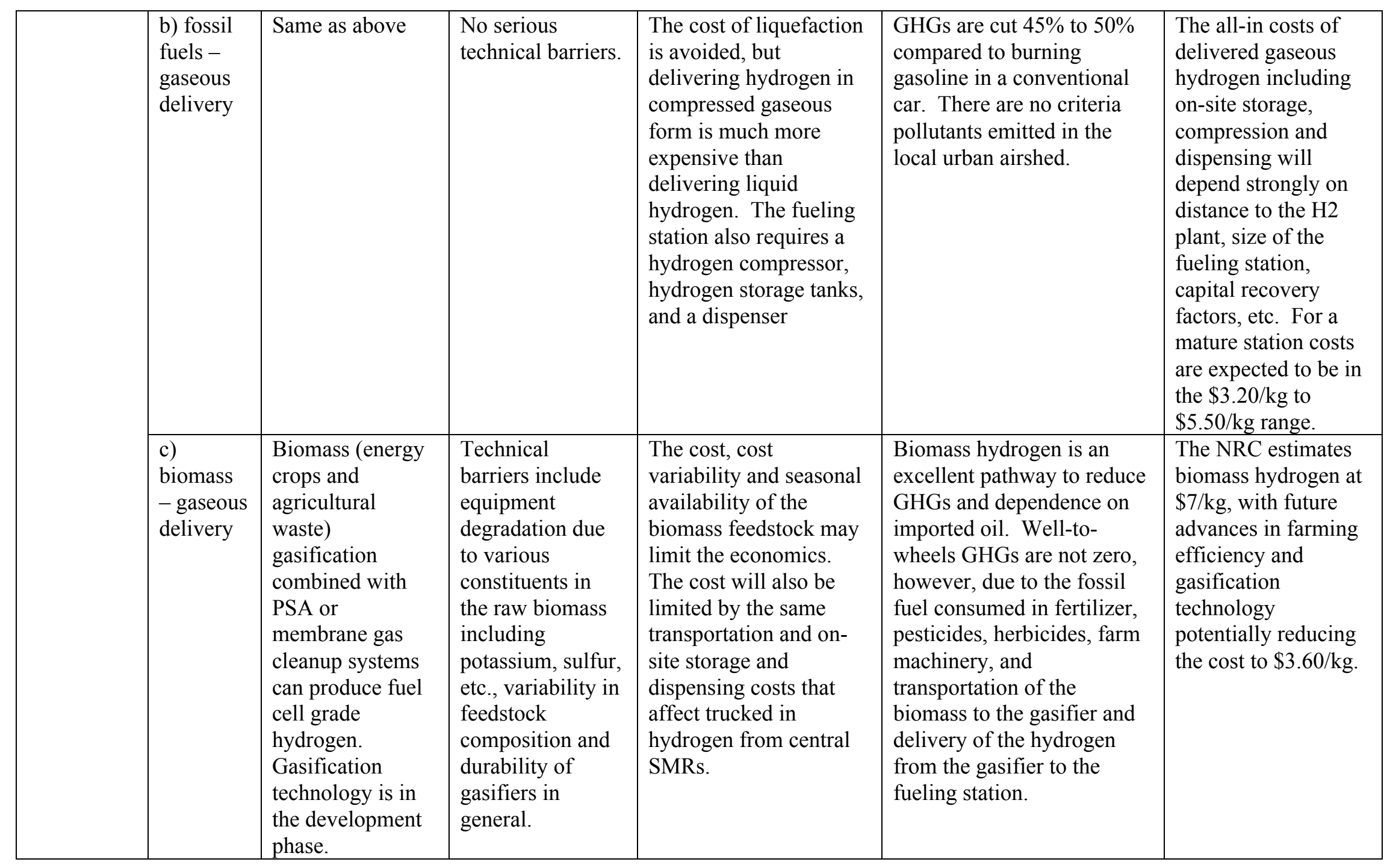




\section{Photobiological and Photoelectrochemical}

\section{(a) Photobiological Hydrogen Production}

\section{Technology Overview}

It is a remarkable fact that the same elemental forms of life (e.g. blue-green algae) that first supplied earth's atmosphere with oxygen are also capable of generating hydrogen under special circumstances that must harken back to their initial primitive environment. We owe our existence to such primitive micro-organisms and in the future we may owe our continued high standard of living to them as well, at least in part. Blue-green algae, green algae, purple algae, and photosynthetic bacteria are all being studied for their capability to use sunlight to produce hydrogen. The leading contender to become a commercially viable hydrogen producer is the green algae species Chlamydomonas reinhardtii.

C. reinhardtii were first cultured at Berkeley in 1998, where it was found that they would produce hydrogen when switched to a sulfur-deficient anaerobic environment. The hydrogen was produced for only a limited period of time, however, after which the green algae had to be placed back in their normal sulfurous, oxygenated environment in order to revitalize and be ready to continue hydrogen production. Subsequently, researchers at Berkeley managed to produce hydrogen continuously using a series of two flow bioreactors that provide the green algae with environments for hydrogen production and revitalization.

In contrast to electrolysis, which requires electricity to split water, these primitive algae and bacteria are able to produce hydrogen from water using catalytic enzymes that they manufacture. Furthermore, hydrogen production using micro-organisms is scalable, which allows production to be either distributed or centralized. Production can be distributed or centralized because what is mainly needed to produce hydrogen is a proper habitat for the algae and that may vary in size: the press has dubbed this environment "slime ponds." In actuality, it consists of a photo-bioreactor, a means of hydrogen extraction and storage, and, preferably, sunlight. Artificial light could be used, but that would involve using electricity. Since Southern California has an abundance of sunlight, it is a particularly advantageous place for distributive production while Northern California has the advantage of being the center of major research into photobiology.

In its present early stage of development, the limitation to photobiological hydrogen production is inefficiency. The present (solar to hydrogen conversion) efficiency is only $0.5 \%$. Besides this limitation, there is the constraint that comes with requiring light. Because they depend upon light, photobiological processes lose efficiency on cloudy days and at greater pond depths and of course are not operational at night. DOE's funding of research into photobiological hydrogen production is aimed at overcoming the limitation on efficiency, and a goal of 5\% efficiency by 2010 has been set. The thrust of the current DOE-funded work is on $C$. reinhardtii. The DOE has identified two basic areas in which breakthroughs must be made in order to increase efficiency and reduce costs: genetic engineering and photobioreactor engineering. 
Successful genetic modifications would significantly increase the green algae's capability to produce hydrogen by removing inhibitions to hydrogen production within the microorganism itself. For instance, green algae co-produce oxygen, which inhibits the hydrogen-producing enzyme. The size of the chlorophyll antenna that the algae use for direct photobiological hydrogen generation, presents another problem. Under bright sunlight, this chlorophyll antenna absorbs much more light than can be used for photosynthetic electron transport, resulting in heat dissipation and the loss of up to $80 \%$ of the absorbed light. By inefficiently absorbing so much light, the algae higher up in the bioreactor steal photons from algae at lower levels, reducing overall production.

System engineering systems breakthroughs would significantly reduce cost. Because of the large size of the hydrogen production "ponds," the photobioreactor cost must be minimized. However, until more information is provided on what materials are appropriate for use in the photobioreactors, it is hard to estimate how low the reactor cost can be made.

\section{Availability}

Photobiological hydrogen production today is still at the basic R\&D stage. Nonetheless, photobiology has attracted some commercial interest. One company, Melis Energy located in Santa Barbara California, is setting up to create commercial hydrogen using the green algae. Barring an unforeseen breakthrough, however, photobiology is not likely to be commercially viable until after 2015 . In order to meet the hurdles of commercial viability several goals have been establish for photobiological hydrogen, including: a) system costs will be able to reach $\$ 30 / \mathrm{kg}$ by 2010 and $\$ 5 / \mathrm{kg}$ by 2015 ; and that b) the biological system will reach $20 \%$ efficiency for absorbed light (but even with this the system will likely not exceed $5 \%$ efficiency of light to $\mathrm{H}_{2}$ conversion by 2010). To make commercial use of the green algae possible by 2015 and achieve the goal of 5\% efficiency, researchers are looking to reduce the chlorophyll antenna size of green algae by $58 \%$, breed more oxygen tolerant algae, and achieve 6 months continuous hydrogen production by 2010 .

\section{Costs}

High reactor costs and low hydrogen output are the major roadblocks to commercialization. If the photo-bioreactor's cost can be significantly reduced (to $\$ 1 / \mathrm{m}^{2}$ ), then photobiological systems with an efficiency of $5 \%$ can produce hydrogen at DOE's ultimate goal of $\$ 2.60 / \mathrm{kg}$. To meet this cost goal, the ideal photo-bioreactor system would use a hydrogen pipeline as a delivery system and would have to be a continuous hydrogen production system with no pressure swing adsorption (PSA) unit; and no compression (see references, Amos 2004). More information needs to be collected on photobioreactor costs as well as other costs drivers such as hydrogen collection systems, continuous bioreactor operation, land area requirements, and capital costs. Understanding these costs is particular important since such investment costs are expected to be almost $90 \%$ of the expenses involved in photobiological hydrogen production.

The DOE's cost, efficiency, and production research goals for photobiological hydrogen production are given in the following table. 


\begin{tabular}{|l|l|l|l|l|}
\hline Characteristics & Units & 2003 Status & 2005 Target & 2010 Target \\
\hline $\begin{array}{l}\text { Solar-to-Hydrogen } \\
\text { Efficiency }\end{array}$ & $\%$ & 0.1 & 0.5 & 5 \\
\hline $\begin{array}{l}\text { Continuous photo- } \\
\text { production } \\
\text { (Durability) }\end{array}$ & hours & & 500 & 1500 \\
\hline Cost & $\$ / \mathrm{kg}$ & $\mathrm{N} / \mathrm{A}$ & $\$ 100$ & $\$ 30$ \\
\hline
\end{tabular}

The costs are for low-pressure hydrogen, at the plant-gate. Little is provided in these DOE goals related to actual hydrogen output.

In summation, two breakthroughs are likely to move photo-biological hydrogen production more rapidly to commercialization: 1) An acceptably high rate of hydrogen output, which depends upon solar-to-hydrogen conversion efficiency and 2) lower photobioreactor costs.

\section{(b) Photoelectrochemical Hydrogen Production}

\section{Technology Overview}

Photoelectrochemical (PEC) hydrogen production is sometimes described as artificial photosynthesis because it resembles the initial stages of photosynthesis in green plants. What PEC and photobiological systems have in common is the ability to perform photoconversion, which is the act of splitting water into hydrogen and oxygen using light. In its simplest form, a PEC cell accomplishes this conversion using a photovoltaic (PV) semiconductor electrode, a metal counter electrode, and an aqueous electrolyte. When light is incident on the PV semiconductor electrode, the electrode absorbs photons resulting in promotion of electrons to the conduction band and oxidation or reduction of species (in this case, water) in the solution adjacent to the electrode. Electricity flows between the semiconductor and counter electrode. The result is the production of hydrogen and oxygen gases separately at the two electrodes. While inorganic PV systems are favored in research, the investigation of hybrid photovoltaic devices (e.g., metalloporphyrin coated semiconductor electrodes) constitutes a second key research area.

The advantages of PEC systems are similar to the advantages of photobiological systems. They require no external source of electricity, and have no emissions. Hydrogen production using photoelectrochemical systems is scalable. The photoelectrochemical cells or banks of cells that compose a system can vary in size, and their size variability makes them candidates for either distributed or centralized production. While the efficiency of PEC cells is higher when using the more expensive crystalline materials, solar efficiencies of up to $7 \%$ can be achieved using less costly amorphous materials (higher efficiencies have been claimed in the literature although these are not generally widely accessible). This level of efficiency is significantly higher than photobiological systems are currently able to achieve. 
Electrolyte leakage has been an intrinsic problem with PECs. Recent developments of solid electrolytes have ameliorated this problem. This is a significant breakthrough. However daunting challenges remain.

What has limited both the efficiency and durability of PECs is that these attributes seem to be mutually antagonistic in the materials investigated so far; that is, materials which have been shown to have greater efficiency have tended to be less durable and vice versa. Similarly, semiconductor materials that have the more optimal band gaps for electricity production for water splitting have had disappointingly low visible light spectrum absorption capability and vice versa. PEC systems are also constrained by diurnal operation limitations. Like photobiological systems, they depend upon light and, of course, are not operational at night without the presence of artificial light. For photoelectrochemical systems to be commercially viable, therefore, other breakthroughs will be required to a) improve the solar-to-hydrogen conversion efficiency of photoelectrochemical systems, b) to improve semiconductor durability and c) to improve PEC design and manufacture for mass manufacturing.

These breakthroughs are expected by the DOE to come principally through the discovery of new materials that are both less costly and more efficient and through low-cost PEC engineering. For instance, because they require neither high-temperature processing or a exceptionally clean, high vacuum manufacturing environment, organic photovoltaic devices could potentially be used to reduce manufacturing costs significantly below those of inorganic PV-based PEC systems.

\section{Availability}

Like photobiological production, PEC technology is still in the R\&D stage. It is not anticipated that solar hydrogen production using PEC technology will make a significant impact on hydrogen production until well after 2010. Low volume distributed production is the most logical pathway in the 2010-2025 timeframe.

\section{Costs}

While commercial production is years off, in 2004 the DOE set some impressive goals for photoelectrochemical hydrogen production.

\begin{tabular}{|l|l|l|l|l|l|}
\hline Characteristics & Units & 2003 Status & 2005 Target & 2010 Target & $\begin{array}{l}\text { 2015 } \\
\text { Target }\end{array}$ \\
\hline $\begin{array}{l}\text { Solar-to-Hydrogen } \\
\text { Efficiency }\end{array}$ & $\%$ & 7 & 7.5 & 9 & 14 \\
\hline Durability & hours & 100 & 1,000 & 10,000 & 20,000 \\
\hline Cost & $\$ / \mathrm{kg} \mathrm{H}$ & N/A & 360 & 22 & 5 \\
\hline
\end{tabular}

These costs are for low-pressure hydrogen, at the plant-gate. No delivery cost or production level goals are currently set for centralized production. 
In summation, it is assumed that two breakthroughs would move PEC hydrogen production rapidly to commercialization: 1) the discovery of new materials with 2015 target efficiencies and durabilities and 2) engineering costs around $\$ 5 / \mathrm{kg}$ using present dollars. 
Photolytic Hydrogen Production

\begin{tabular}{|c|c|c|c|c|c|}
\hline Production Mode & $\begin{array}{l}\text { Development Status/ Industry } \\
\text { Readiness }\end{array}$ & Technical Barriers & $\begin{array}{l}\text { Economic } \\
\text { Barriers }\end{array}$ & $\begin{array}{l}\text { Environmental } \\
\text { Considerations }\end{array}$ & $\begin{array}{l}\text { Project } \\
\text { ed Cost }\end{array}$ \\
\hline
\end{tabular}




\section{Coal Gasification with $\mathrm{CO}_{2}$ Capture and Sequestration}

\section{Technology Overview}

Hydrogen can be produced at large scale by gasification of low-cost solid hydrocarbon feedstocks such as coal, petroleum coke, wastes or biomass. The feedstock is reacted with oxygen (either pure oxygen or air) and steam at high temperature producing a synthetic gas or "syngas, " comprised of hydrogen, carbon monoxide $(\mathrm{CO})$, carbon dioxide $\left(\mathrm{CO}_{2}\right)$, water vapor $\left(\mathrm{H}_{2} \mathrm{O}\right)$ and methane $\left(\mathrm{CH}_{4}\right)$. The syngas is further processed in a water gas shift stage to increase the hydrogen content, and pure hydrogen is separated out of the mixture. Coal-to-hydrogen routes are potentially important, because coal is a low-cost, large resource in the United States, and in other countries with high energy use such as China and India. However, it is recognized that within California itself that coal currently contributes less than one percent to total power capacity, a number probably not likely to increase dramatically in the future. However, it is noted that California imports significant electricity generated at out-of-state coal power plants.

A major environmental issue for coal-derived liquid fuels is carbon emissions to the atmosphere during their production and use. However, when hydrogen is made from hydrocarbons, carbon dioxide can be separated, compressed, transported by pipeline and "sequestered" in secure underground storage sites such as deep saline aquifers or depleted oil and gas fields. This would allow continued use of fossil-derived fuels, with near-zero emissions of carbon to the atmosphere. The technologies for capturing, transporting and injecting carbon dioxide into geological formations are well known in the oil industry where carbon dioxide is piped and injected into oil reservoirs for enhanced oil recovery. Several demonstrations of $\mathrm{CO}_{2}$ sequestration are ongoing in the United States and Europe (USDOE Carbon Sequestration Technology Roadmap and Program Plan 2004). Carbon capture and sequestration are important enabling technologies for fossil hydrogen as a long term, low carbon emitting option. However, there are still many unanswered scientific and cost questions about long-term storage of carbon dioxide.

\section{Near Term Technologies 2004-2010}

The chemical process technologies to produce hydrogen at large scale from coal are well established and commercially available. In the US, coal-derived industrial hydrogen is a minor player, about $95 \%$ of hydrogen is made from natural gas, but worldwide about $30 \%$ of industrial hydrogen is produced from coal-derived syngas (USDOE Hydrogen Program website 2004). Much of this capacity is in coal-rich nations such as China. While it is believed to be technically feasible today, none of the industrial coal-to-hydrogen facilities currently capture $\mathrm{CO}_{2}$ (USDOE Hydrogen from Coal RD\&D Draft Plan 2004).

\section{Technologies Available in the 2015-2030 timeframe}

Advanced systems for co-production of electricity and hydrogen from coal with $\mathrm{CO}_{2}$ capture are under development. In 2003, the US DOE announced the \$1 billion "FutureGen" program, with the goal of producing electricity and hydrogen from coal, while capturing and sequestering $\mathrm{CO}_{2}$. The USDOE Future Gen Program has set a 2015 goal of demonstrating a 60\% efficient, zero- 
emission coal plant producing $275 \mathrm{MW}$ of hydrogen and electric power with carbon capture and sequestration at a $25 \%$ cost reduction over current coal-to-hydrogen technology. (Source: Hydrogen Posture Plan 2004; USDOE FutureGen Report 2004). In addition to funding for the FutureGen Initiative, funding for ancillary coal-to-hydrogen RD\&D was $\$ 4.9 \mathrm{M}$ (FY'04) and $\$ 16 \mathrm{M}$ is requested for FY'05.

\section{Scalability}

Coal gasification with $\mathrm{CO}_{2}$ sequestration is inherently a large-scale centralized production option, and hydrogen distribution would be required to refueling stations. This is unlike the case for natural gas steam reforming where onsite production would be possible. Gasifiers, a major contributor to the plant capital cost and the levelized hydrogen cost, exhibit strong scale economies, so large plants are favored. Similarly, $\mathrm{CO}_{2}$ disposal pipelines and injection wells only make economic sense when large $\mathrm{CO}_{2}$ flows are involved corresponding to large coal plants. Hydrogen production might be "ramped up" over time in a large fossil energy complex producing both electricity and hydrogen, with $\mathrm{CO}_{2}$ capture-hence the National Research Council recommendation that coal-to-hydrogen production should serve as a longer-term option. Alternatively, liquid fuels might be made from coal and subsequently reformed to make hydrogen, although less carbon could be captured and sequestered in this case.

\section{System and Feedstock Costs}

Using current technology, the plant gate production cost of hydrogen via coal gasification with $\mathrm{CO}_{2}$ capture and sequestration has been estimated to cost about $\$ 1.1 / \mathrm{kg}$ of hydrogen (see table below, adapted from Mitretek 2002), similar to the cost of hydrogen from natural gas. Much of the production cost is due to capital costs of the plant since coal feedstock costs are a relatively small contributor. Opportunities exist to reduce plant capital costs by improved technologies and integrated design, leading to projected lower costs in 2015. When electricity is a major co-product, hydrogen could be made at even lower costs. 


\begin{tabular}{|l|l|l|l|}
\hline Technological Readiness & $\begin{array}{l}\text { Case 1: } \\
\text { (Current technology) }\end{array}$ & $\begin{array}{l}\text { Case 2: 2015 } \\
\text { (Advanced } \\
\text { technology) } \\
\text { H2 is primary output }\end{array}$ & $\begin{array}{l}\text { Case 3: 2015 } \\
\text { (Advanced technology) } \\
\text { Electricity is major co- } \\
\text { product }\end{array}$ \\
\hline Carbon Sequestration (fraction captured) & $\begin{array}{l}\text { Yes } \\
(87 \%)\end{array}$ & $\begin{array}{l}\text { Yes } \\
(100 \%)\end{array}$ & $\begin{array}{l}\text { Yes } \\
(100 \%)\end{array}$ \\
\hline & 119 & 158 & 153 \\
Hydrogen production (million scf/d) & 470 & 630 & 610 \\
MW H2 output HHV basis & 290 & 380 & 370 \\
tonne H2/day & 3000 & 3000 & 6000 \\
\hline Coal use (tons/day) & 860 & 860 & 1730 \\
\hline H2 FCVs served & 400,000 & 530,000 & 510,000 \\
\hline Efficiency coal-> energy (HHV) & 59 & 75.5 & 59 \\
\hline Excess Power (MW) & 27 & 25 & 417 \\
\hline Power value (cents/kWh) & 5.36 & 5.36 & 5.36 \\
\hline Capital Cost million \$ & 417 & 425 & 950 \\
\hline Levelized H2 Cost \$/kg & 1.10 & 0.79 & 0.54 \\
\hline
\end{tabular}

Source: USDOE Coal from Hydrogen RD\&D Draft Plan 2004; Mitretek 2002.

\section{Scientific and Engineering Challenges to Reduce Costs}

The main challenges to reducing costs for hydrogen via coal gasification with $\mathrm{CO}_{2}$ capture are reducing the capital cost of the process equipment, including: development of new water gas shift catalysts, new technologies for hydrogen and $\mathrm{CO}_{2}$ separation such as membranes, and novel process technologies that combine several process steps (USDOE Hydrogen from Coal Program Plan, 2004). In addition, research now underway for coal-fired electricity production is key for hydrogen from coal gasification, including RD\&D on: advanced efficient coal gasification systems; advanced syngas clean-up; fuel cells or hydrogen turbines for electric co-production (DOE Hydrogen from Coal RD\&D Draft Plan 2004). Finally, there are many challenges remaining in understanding the science and engineering of $\mathrm{CO} 2$ sequestration (USDOE Carbon Sequestration Technology Roadmap and Program Plan 2004).

\section{Industry Leaders}

The USDOE is leading demonstration on advanced coal to hydrogen systems with $\mathrm{CO}_{2}$ sequestration through the FutureGen program, and the Carbon Sequestration Regional Partnerships. The Carbon Capture Project (CCP), an industry working group includes many major energy and chemical companies. Companies active in coal-to-hydrogen and $\mathrm{CO}_{2}$ sequestration include Fluor Daniel, Praxair, Alstom Power, SIMTECHE and Nexant.

\section{California Activities and Issues}

Hydrogen production from coal may have modest application in California, as relatively little of California's energy currently comes from coal, as compared to the US average. In California, the 
West Coast Regional Carbon Sequestration Partnership, supported by the USDOE and led by the California Energy Commission, plans to identify, characterize and locate $\mathrm{CO}_{2}$ emission sources in the region and determine long-term capturing and sequestering methods by enlisting the help of numerous federal, state, local government agencies and industry sources. A list of partners is found at the USDOE website http://www.fe.doe.gov/programs/sequestration/partnerships/2003sel_westcoast.html RD\&D Projects related to carbon sequestration in California are listed at: http://www.fossil.energy.gov/fred/feprograms.jsp?prog=Carbon+Sequestration\&state=CA

A summary table for production of hydrogen by coal gasification is presented at the end of section 6 .

\section{Biomass Gasification}

\section{Technology Overview}

Hydrogen can be produced at large scale by gasification of biomass or wastes. The feedstock is reacted with oxygen (either pure oxygen or air) and steam at high temperature producing a synthetic gas or "syngas, " comprised of hydrogen, carbon monoxide $(\mathrm{CO})$, carbon dioxide $\left(\mathrm{CO}_{2}\right)$, water vapor $\left(\mathrm{H}_{2} \mathrm{O}\right)$ and methane $\left(\mathrm{CH}_{4}\right)$. The syngas is further processed in a water gas shift stage to increase the hydrogen content, and pure hydrogen is separated out of the mixture. Biomass-tohydrogen routes are potentially important, because biomass is a low-cost, large resource in the United States, and in many parts of the world, especially in developing countries.

Assuming the biomass is produced renewably, there are no net carbon emissions to the atmosphere. It has been suggested that biomass hydrogen could even become a net carbon sink, if carbon dioxide is captured and sequestered. A challenge for biomass is that a relatively large amount of land is needed. Biomass hydrogen strategies must consider competing high-value uses for lowcost biomass (electricity production), land use, and environmental impacts of energy crops.

\section{Near Term Technologies 2004-2010}

Biomass gasifiers exist, and there has been extensive testing and demonstration of small scale biomass gasifiers (see Milne et al. 2001 for an excellent review).

\section{Technologies Available in the 2015-2030 timeframe}

Advanced systems for biomass gasification are being investigated at NREL and at Iowa State. The USDOE has set a 2015 goal of demonstrating a biomass gasifier resulting in a hydrogen cost of $\$ 2.9 / \mathrm{kg} \mathrm{H}$ at the plant gate. (Devlin 2004). Current and proposed DOE annual funding levels for biomass to hydrogen RD\&D are \$0.5M (FY'04); \$1.5 M is requested for FY'05 (Chalk 2004).

\section{Scalability}

As with coal gasification, biomass gasifiers are an expensive part of the system, and exhibit scale economies. This suggests that biomass gasifiers should be large, central plants. But very large biomass gasifiers would require large quantities of biomass (gathered over a wide area), which is 
generally expensive to store and transport long distances. With biomass there is a trade-off between lower capital costs at large plant size, and lower biomass feedstock transport costs at small plant size. The typical unit size for a biomass gasification plant is likely to be much smaller than for a coal plant, unless a large, low cost feedstock source exists nearby.

\section{System and Feedstock Costs}

The plant gate production cost of hydrogen via biomass gasification is currently about $\$ 3.6 / \mathrm{kg}$ of hydrogen according to USDOE estimates (Spath and Mann 2000; USDOE Hydrogen and Fuel Cells Multiyear Program Plan 2003). A breakdown of costs based on a conceptual design study at NREL (Spath, Lane, Mann and Amos 2001) is shown in the table below. The unit size for the biomass plant is taken to be 75 tonnes per day, about 1/5th the size of a typical coal-to-hydrogen plant. Major cost factors are process equipment capital costs, especially for the gasifier, and biomass feedstock costs.

\begin{tabular}{|l|l|l|l|}
\hline & 2003 & 2010 Target & 2015 Target \\
\hline Biomass Feedstock Cost & & $\$ 42 /$ bone dry ton & \\
\hline $\begin{array}{l}\text { Hydrogen production } \\
\text { tonne } \mathrm{H}_{2} / \text { day }\end{array}$ & 75 & 75 & 75 \\
\hline Biomass use (bone dry tons/day) & 1000 & 1000 & 1000 \\
\hline $\mathrm{H} 2$ FCVs served & 100,000 & 100,000 & 100,000 \\
\hline Overall Efficiency biomass-> $\mathrm{H}_{2}(\mathrm{LHV})$ & $42.8 \%$ & $51.3 \%$ & $62.5 \%$ \\
\hline Gasifier eff $(\mathrm{LHV})$ & $68 \%$ & $75 \%$ & $82 \%$ \\
\hline Reformer eff & $85 \%$ & $89 \%$ & $93 \%$ \\
\hline Purification eff & $74 \%$ & $77 \%$ & $82 \%$ \\
\hline Total H2 Plant gate Cost \$/kg & 3.60 & 2.60 & 2.00 \\
\hline Feedstock \$/kg & 0.8 & 0.6 & 0.5 \\
\hline Gasifier \$/kg & 1.6 & 1.2 & 1.0 \\
\hline Reforming \$/kg & 0.5 & 0.4 & 0.2 \\
\hline Purification \$/kg & 0.4 & 0.3 & 0.3 \\
\hline
\end{tabular}

Other cost estimates for biomass gasifiers show similar costs. Simbeck and Chang (2002) estimated hydrogen plant gate cost of $\$ 2.29 / \mathrm{kg}$ for a 150 tonne/day hydrogen plant (twice the size of Spath et al.'s case). The National Academy of Engineering's recent report (NAE 2004) suggested that the cost of hydrogen from biomass gasification would be $\$ 4.5 / \mathrm{kg}$ for current technology, and $\$ 2.2 / \mathrm{kg}$ for future technology, for a plant producing 150 tonne/day of hydrogen.

\section{Scientific and Engineering Challenges}

As summarized in several reports by the USDOE (Hydrogen Multiyear Program Plan 2003) and the IEA (Milne et al. 2001), there are ample opportunities to make technical improvements that could reduce costs of hydrogen from biomass gasification systems. Process equipment improvements include better reformer catalysts, better process heat integration, higher gasifier pressure, better feedstock handling, and improved gas clean-up. Moreover, lower cost biomass collection, storage and transport methods could yield lower feedstock costs. As shown in the table above, the greatest improvements are projected in the capital cost of the gasifier and in lower 
feedstock cost contributions, because of increased efficiency of conversion in each stage. [This is especially true for the gasifier where the efficiency is projected to increase from $68 \%$ (LHV basis) to $75 \%$ in 2010 and $82 \%$ by 2015 .]

\section{Industry leaders}

The USDOE is leading demonstration of advanced biomass to hydrogen systems. In California, there are significant biomass resources, including forest product and agricultural wastes that might be used for hydrogen production.

A summary table for biomass gasification is presented at the end of section 6 .

\section{High Temperature Thermochemical Water splitting}

\section{Technology Overview}

It is thermodynamically possible to split water directly into hydrogen and oxygen using heat at $4000{ }^{\circ} \mathrm{C}$, although is impractical to work at these high temperatures with current materials. However, water splitting can also be accomplished through a complex series of coupled chemical reactions driven by heat at $400-1000{ }^{\circ} \mathrm{C}$ from nuclear reactors or solar concentrators. A number of thermochemical water splitting cycles have been investigated for use with nuclear or solar heat (Yalcin 1989). A recent assessment of nuclear hydrogen production (Brown 2002) identified the sulfur-iodine process as one of the most promising cycles. Thermochemical water splitting cycles are still undergoing research, and are not as technically mature as fossil hydrogen production systems such as steam reforming, coal gasification or water electrolysis, and should be considered a longer-term possibility.

The attraction of high temperature thermochemical cycles is that they could use heat derived from widely available, non-carbon emitting sources such as nuclear power or solar energy to accomplish water splitting. The hope is that this would yield a lower hydrogen cost than electrolysis, which requires electricity input. As with electrolysis, the environmental and security impacts of thermochemical cycles depend on the primary source of energy (in this case heat). For example, if nuclear heat is used, there will be many of the same issues as with nuclear electricity.

\section{Near Term Technologies 2004-2010}

The technology is in an early stage of development, and needs significantly more development before it can be tested for hydrogen production. Individual parts of the system have been tested, but a complete integrated system is still under development in the laboratory. The USDOE Office of Nuclear Energy, Science and Technology is leading research on these systems. Current and proposed DOE Funding levels for nuclear thermochemical hydrogen RD\&D: \$6.4M (FY'04); \$9.0 M is requested in FY'05 (Chalk 2004). Recently a project has begun to investigate using high temperature solar heat to power thermochemical cycles. DOE funding for this effort is projected to start in FY'05 at \$1.25 million. 


\section{Technologies Available in the 2015-2030 timeframe}

The USDOE has stated a goal for 2015 of producing hydrogen via high temperature thermochemical processes with a projected cost competitive with gasoline. (Hydrogen and Fuel Cells: Multiyear Program Plan 2003). Given the nascent stage of the technology, it is unclear how long it will take to develop.

\section{Scalability}

High temperature thermochemical reactors could in theory be made at small size. If the source of heat is from nuclear reactions, the system is likely to be large scale, as nuclear technologies have strong scale economies, as well as safety and security issues favoring centralized plants. For solar-derived heat, there could be a range of sizes. Because of the early status of the technology, no optimizations for system size have been performed.

\section{System and Feedstock Costs}

It is difficult to make economic estimates for high temperature thermochemical systems with certainty, as the technology is still at the laboratory stage. The USDOE has set forth what seem to be extremely ambitious goals for this technology, shown in the table below (USDOE Multiyear Program Plan 2003, Table 3.1.9).

\begin{tabular}{|l|l|l|l|}
\hline & 2003 & 2005 Target & 2010 \\
\hline High Temperature Production $\left(700-900^{\circ} \mathrm{C}\right)$ & & & \\
\hline Cost at the plant $\$ / \mathrm{kg}$ & na & 10 & 2 \\
\hline Energy Efficiency & na & $25 \%$ & $40 \%$ \\
\hline $\begin{array}{l}\text { Ultra High Temperature Solar Production } \\
\left(>1500^{\circ} \mathrm{C}\right)\end{array}$ & & & \\
\hline Cost at the plant $\$ / \mathrm{kg}$ & 12 & 8 & 4 \\
\hline Solar concentrator cost $\$ / \mathrm{m}^{2}$ & 250 & 130 & 75 \\
\hline Process efficiency & $20 \%$ & $40 \%$ & $45 \%$ \\
\hline
\end{tabular}

\section{Scientific and Engineering Challenges to Reduce Costs}

The USDOE Multiyear program plan lays out a daunting array of challenges for high temperature thermochemical hydrogen production. These include: 1) hydrogen production from these technologies has not been proven, and components and subsystems have not been evaluated; new cost-effective materials that can withstand the high temperatures and temperature cycling need to be developed, there are public acceptance issues with nuclear power, solar collectors are still quite expensive. 


\section{Industry leaders/California Activities}

The USDOE is leading demonstration of the technology through The Office of Energy Efficiency and Renewable Energy and the Office of Nuclear Science and Technology (http://www.ne.doe.gov/hydrogen/hydrogenBG.html). The University of Nevada is leading the solar experiments, and General Atomics in San Diego has been involved with the nuclear hydrogen work. 


\section{Summary Table: H2 Production Technologies by Coal Gasification, Biomass Gasification, and High Temperature}

Thermochemical

\begin{tabular}{|c|c|c|c|c|c|c|c|}
\hline \multicolumn{2}{|c|}{ Production / Delivery Mode } & $\begin{array}{l}\text { Development } \\
\text { Status/ Industry } \\
\text { Readiness }\end{array}$ & Technical Barriers & $\begin{array}{l}\text { Economic Barriers } \\
\text { Canital cost of process }\end{array}$ & $\begin{array}{l}\text { Environmental } \\
\text { Considerations }\end{array}$ & $\begin{array}{l}\text { Special CA } \\
\text { factors }\end{array}$ & $\begin{array}{l}\text { Projected } \\
\text { Costs } \\
2010 \\
\$ / \mathrm{kg} \\
\end{array}$ \\
\hline $\begin{array}{l}\text { Coal } \\
\text { Gasification } \\
\text { with } \mathrm{CO}_{2} \\
\text { Capture and } \\
\text { Sequestration } \\
\text { Large, central } \\
\text { option: not } \\
\text { scalable } \\
\text { (150-600 } \\
\text { t/day } \mathrm{H} 2)\end{array}$ & $\begin{array}{l}\text { Compressed } \\
\text { Gas or LH2 } \\
\text { Truck or Gas } \\
\text { Pipeline }\end{array}$ & $\begin{array}{l}\text { Coal gasification is } \\
\text { commercial } \\
\text { technology; } \mathrm{CO}_{2} \\
\text { capture and } \\
\text { sequestration } \\
\text { demonstrations on- } \\
\text { going; could be } \\
\text { developed in near } \\
\text { term }\end{array}$ & $\begin{array}{l}\text { Technical barriers } \\
\text { center on cost } \\
\text { reduction rather than } \\
\text { feasibility. } \mathrm{CO}_{2} \\
\text { sequestration is still } \\
\text { being proven via } \\
\text { large scale demos. }\end{array}$ & $\begin{array}{l}\text { Capital cost of process } \\
\text { equipment: water gas } \\
\text { shift catalysts, } \\
\text { hydrogen and } \mathrm{CO}_{2} \\
\text { separation tech } \\
\text { (membranes), combine } \\
\text { several process steps. } \\
\text { Reduce cost via RD\&D } \\
\text { on: advanced efficient } \\
\text { coal gasification } \\
\text { systems; advanced } \\
\text { syngas clean-up; fuel } \\
\text { cells or hydrogen } \\
\text { turbines for electric co- } \\
\text { production. }\end{array}$ & $\begin{array}{l}\text { Impact of } \mathrm{CO}_{2} \\
\text { on underground } \\
\text { storage } \\
\text { reservoirs; need } \\
\text { for long term } \\
\text { monitoring to } \\
\text { detect leaks }\end{array}$ & $\begin{array}{l}\text { Coal is a } \\
\text { relatively } \\
\text { small part of } \\
\text { CA's energy } \\
\text { mix today; } \\
\text { many } \mathrm{CO}_{2} \\
\text { sequestration } \\
\text { activities in } \\
\mathrm{CA}\end{array}$ & $\begin{array}{l}\$ 0.8 / \mathrm{kg} \\
\text { at plant } \\
\text { gate; } \\
\$ 1.8 / \mathrm{kg} \\
\text { delivered } \\
\text { (Note: } \\
\text { This is } \\
\text { USDOE } \\
\text { HPP goal } \\
\text { for 2015) }\end{array}$ \\
\hline $\begin{array}{l}\text { Biomass } \\
\text { Gasification } \\
(75-150 \mathrm{t} / \mathrm{d}) \\
\text { Midsize } \\
\text { central } \\
\text { option, } \\
\text { smaller than } \\
\text { coal } \mathrm{H}_{2} \\
\text { systems }\end{array}$ & $\begin{array}{l}\text { Compressed } \\
\text { Gas or LH2 } \\
\text { Truck or Gas } \\
\text { Pipeline }\end{array}$ & $\begin{array}{l}\text { Demonstrated at } \\
\text { pilot plant scale. }\end{array}$ & $\begin{array}{l}\text { Technical barriers } \\
\text { center on cost } \\
\text { reduction rather than } \\
\text { feasibility. }\end{array}$ & $\begin{array}{l}\text { Cost reductions via } \\
\text { process equipment } \\
\text { improvements } \\
\text { including better } \\
\text { reformer catalysts, } \\
\text { better process heat } \\
\text { integration, higher } \\
\text { gasifier pressure, better } \\
\text { feedstock handling, and } \\
\text { improved gas clean-up. } \\
\text { Lower cost biomass } \\
\text { collection, storage and } \\
\text { transport methods could } \\
\text { yield lower feedstock } \\
\text { costs. }\end{array}$ & $\begin{array}{l}\text { Land use } \\
\text { constraints, } \\
\text { depends on low } \\
\text { cost biomass } \\
\text { feedstocks }\end{array}$ & $\begin{array}{l}\text { Agricultural } \\
\text { and forest } \\
\text { products } \\
\text { feedstocks }\end{array}$ & $\begin{array}{l}\$ 2.9 / \mathrm{kg} \\
\text { at plant } \\
\text { gate } \\
\text { (DOE } \\
2010 \\
\text { goal) }\end{array}$ \\
\hline
\end{tabular}




\begin{tabular}{|c|c|c|c|c|c|c|c|}
\hline $\begin{array}{l}\text { High } \\
\text { temperature } \\
\text { Thermochem } \\
\text { ical } \mathrm{H}_{2} \\
\text { Production } \\
\text { (Nuclear) } \\
\text { Large, central }\end{array}$ & $\begin{array}{l}\text { Compressed } \\
\text { Gas or LH2 } \\
\text { Truck or Gas } \\
\text { Pipeline }\end{array}$ & $\begin{array}{l}\text { Experimental, } \\
\text { laboratory stage }\end{array}$ & $\begin{array}{l}\text { Hydrogen production } \\
\text { from these } \\
\text { technologies has not } \\
\text { been proven, and } \\
\text { subsystems have not } \\
\text { been evaluated; new } \\
\text { cost-effective } \\
\text { materials operating at } \\
\text { high temperatures } \\
\text { and temperature } \\
\text { cycling need to be } \\
\text { developed. }\end{array}$ & $\begin{array}{l}\text { Difficult to estimate } \\
\text { costs because } \\
\text { technology is in early } \\
\text { stage }\end{array}$ & $\begin{array}{l}\text { Same as } \\
\text { nuclear power; } \\
\text { public } \\
\text { acceptance and } \\
\text { policy issues }\end{array}$ & $\begin{array}{l}\text { Research at } \\
\text { General } \\
\text { Atomics, } \\
\text { UNLV }\end{array}$ & $\begin{array}{l}\$ 4 / \mathrm{kg} \text { at } \\
\text { plant gate } \\
\text { (DOE } \\
2010 \\
\text { goal) }\end{array}$ \\
\hline $\begin{array}{l}\text { Thermochem } \\
\text { ical H2 } \\
\text { Production } \\
\text { (Solar). } \\
\text { Size not yet } \\
\text { determined. }\end{array}$ & $\begin{array}{l}\text { Compressed } \\
\text { Gas or LH2 } \\
\text { Truck or Gas } \\
\text { Pipeline }\end{array}$ & $\begin{array}{l}\text { Experimental, } \\
\text { laboratory stage }\end{array}$ & $\begin{array}{l}\text { Hydrogen production } \\
\text { from these } \\
\text { technologies has not } \\
\text { been proven, and } \\
\text { subsystems have not } \\
\text { been evaluated; new } \\
\text { cost-effective } \\
\text { materials operating at } \\
\text { high temperatures } \\
\text { and temperature } \\
\text { cycling need to be } \\
\text { developed. }\end{array}$ & $\begin{array}{l}\text { Difficult to estimate } \\
\text { costs because } \\
\text { technology is in early } \\
\text { stage. Solar } \\
\text { concentrating } \\
\text { collectors expensive. }\end{array}$ & $\begin{array}{l}\text { Land use for } \\
\text { solar } \\
\text { concentrators }\end{array}$ & $\begin{array}{l}\text { Excellent } \\
\text { solar } \\
\text { resource }\end{array}$ & $\begin{array}{l}\$ 4 / \mathrm{kg} \text { at } \\
\text { plant gate } \\
\text { (DOE } \\
2010 \\
\text { goal } \\
\text { Devlin } \\
2004 \text { ) }\end{array}$ \\
\hline
\end{tabular}




\section{Biofermentation}

Direct fermentation of carbohydrate feedstocks by microorganisms is one potential, albeit far-off, technology for the production of hydrogen. While the technical feasibility has been proven, it is uncertain whether this technology can be economically competitive with gasoline or with other hydrogen production pathways. DOE studies suggest that a fermentation yield of 10 moles of hydrogen per mole of glucose and a glucose cost of 5 cents per dry pound will be required for this process to approach hydrogen costs that are competitive with gasoline. DOE has identified the grand challenges for biofermentation as:

- No known microorganism is capable of naturally producing more than 4 moles of hydrogen per mole of glucose - the metabolic pathways have not been identified and it is energetically unfavorable (and we have not discovered a mechanism to enable "reverse" electron flow to hydrogenase).

- Biomass feedstocks are too costly - need to develop low-cost methods for growing, harvesting, transporting, and pretreating energy crops and/or biomass waste products.

- There is no single platform for research - a robust, industrial-capable organism that can produce greater than 4 moles of hydrogen/mole of glucose (or other sugar) has not yet been identified and validated by the research community.

In order to make biofermentation a realistic hydrogen production technology, a number of scientific breakthroughs will be needed. Specifically, scientists will need to identify or genetically engineer an organism that can produce high yields of hydrogen via direct fermentation. System economics must also be improved. Low cost feedstocks must be produced using genetic engineering/breeding of crops. Better system engineering of bioreactors must be accomplished in order to lower cost. Fundamental Studies must be undertaken of complete enzymatic conversion to simplify the overall process. The current cost of hydrogen production using biofermentation is not known with certainty, but is likely more than $\$ 300 / \mathrm{kg}$. It is unlikely that this cost will decrease to less than $\$ 10 / \mathrm{kg}$ before 2015 , if not much later.

\section{Membranes}

\section{Technology Overview}

Hydrogen separation membranes (HSMs) are used to separate $\mathrm{H}_{2}$ molecules from a mixed gas stream to create a permeate significantly purer in $\mathrm{H}_{2}$ than the feedgas. Pressure Swing Absorption (PSA) is the technology used today to separate and purify $\mathrm{H}_{2}$ but is deemed too expensive to reach DOE goals for $\mathrm{H}_{2}$ fueling stations. Therefore, HSMs are integral to implementation of most hydrogen production technologies. HSMs can be grouped into two types of membranes, porous and dense. The types of membranes can be furthered classified into low or high temperature operating regimes. Key considerations for HSMs include hydrogen production rate, purity, cost, and durability. Production rate and purity are based on the permeation properties and the selectivity of the membranes. Both the type and operating temperature dictate the materials of construction, selectivity, suitable gas streams, and cost. These attributes determine the most suitable application for the system incorporating them. 
In porous hydrogen separation membranes (pHSMs), hydrogen is transported through the pores as molecules and the process occurs readily. The pore size of a porous membrane is tailored to discriminate between the desired species and the unwanted species. For example, a pHSM operating in a reformed fuel stream would have its microstructure tailored to allow $\mathrm{H}_{2}$, with a molecular size of $2.89 \AA$, to move through it while blocking other larger gases such as $\mathrm{CO}$ and $\mathrm{CO}_{2}$. Selectivity is based not only molecular size but also on how the molecule moves through a medium (mean free path) and, in many instances, on the viscosity of the gas stream. Permeation rate is impacted by the thickness, tortuosity, and total porosity (pore volume) of the membrane.

Dense hydrogen separation membranes (dHSMs) are comprised of a thin, dense layer supported on a porous layer. In dHSMs, hydrogen is transported in the solid phase as hydrogen ions (protons) or as hydrogen dissolved in the dense matrix. The permeability rate of hydrogen through the dense layer is the product of the hydrogen solubility and the hydrogen diffusion rate.

Low temperature (LT) HSMs are constructed of polymer materials and so have an operating temperature limit of approximately $100^{\circ} \mathrm{C}$. The types of polymer used include polysulfone, polyimide, and tetrabromo polycarbonate with hollow fiber and spiral-wound designs.

High temperature (HT) HSMs are comprised of inorganic materials as the operating temperatures fall between 250 and $1000^{\circ} \mathrm{C}$ and are designed to be used in harsh environments with enhanced robustness in comparison to LT-HSMs. The separation membrane in HTpHSMs is usually made from silica and/or alumina supported by a highly porous metallic or ceramic layer. Zeolite membranes also fall in this category. HT-dHSMs are based on one of three thin $(300$ to $0.1 \mu \mathrm{m})$ membrane material types: metal, ceramic, or cermet (ceramicmetal composite). Metal HT-dHSM membranes are comprised of palladium (due the high solubility of hydrogen in palladium) on a porous ceramic support and are designed to operate between 300 and $600^{\circ} \mathrm{C}$. Ceramic HT-dHSMs require materials with high protonic conductivity, high electronic conductivity and low oxygen ionic conductivity such as doped $\mathrm{SrCeO}_{3}$ and doped $\mathrm{BaCeO}_{3}$. In principle, both metal and ceramic HT-dHSMs can produce very high purity hydrogen because only hydrogen is transported through the membrane. Cermet HT-dHSMs are being developed to improve the mechanical, electrical, and catalytic properties with respect to pure ceramic HT-dHSMs while lowering the cost with respect to Pd-based HT-dHSMs. Along with high flux and selectivity, HT-HSMs should exhibit compatibility and stability in environments typical of the feed and permeate.

An advantage of HT-dHSMs is that their potential chemical and thermal durability makes it possible to integrate them with one of several $\mathrm{H}_{2}$ generation technologies to create simplified, compact catalytic reformer/separator systems, called Catalytic Membrane Reactors (CMRs). To produce $\mathrm{H}_{2}$ directly from natural gas, a CMR with a catalyst coating on the feed side is used to produce protons and electrons that are transported through a mixed-conducting dHSM to the permeate side where the protons are reduced to $\mathrm{H}_{2}$. Candidate membrane materials show promise but currently do not have enough electronic conductivity or environmental stability. To circumvent this issue, Praxair and Air Products are pursuing a dual membrane separator system. The first membrane separator is a natural gas/air CMR that 
partially oxidizes the methane into syngas $\left(\mathrm{H}_{2}\right.$ and $\left.\mathrm{CO}\right)$. The syngas is then feed to the second membrane, a Pd alloy-based dHSM, that yields a high purity $\mathrm{H}_{2}$ permeate. Both of these configurations will utilize catalysts for partial oxidation or auto-thermal reforming from reformer technology. A configuration that is in early development stage but has greater environmental and economic payoff is the integration of photolytic catalysts on HSMs to create efficient, inexpensive solar-to-hydrogen systems (see Photoelectrochemical section). Though LT-HSMs could be used for these systems, thermal, chemical, and UV stability demands will likely drive them towards to ceramic HT-HSMs.

\section{Technical barriers}

In order to fully exploit the unique capabilities of the HT-HSMs, they must be sealed to a dense ceramic or a metal support structure. Commonly used seals are not suitable for these applications because their heat resistance is ineffective above $400^{\circ} \mathrm{C}$ and their sealing processes require higher yields. Additionally, HT-pHSMs suffer from loss of porosity at high temperatures. For HT-dHSMs, the focus is on decreasing the Pd content for metal and cermet membranes while increasing the stability and electronic conductivity of mixed ionic and electronic conducting (MIEC) materials. Additionally, cost-effective methods for fabricating the thin-film membranes on the porous supports are essential to the commercialization of HTHSMs. LT-HSMs are susceptible to fouling from higher hydrocarbon and sulfur contaminants in natural gas feeds. Furthermore, they do not operate well under dynamic conditions likely to be encountered in a $\mathrm{H}_{2}$-fueling station. However, they may be the most suitable approach for $\mathrm{H}_{2}-\mathrm{O}_{2}$ separation in tandem with photolysis systems. A large component of cost in any of these systems is the compressor for the $\mathrm{H}_{2}$ permeate. Therefore, system designs amenable to producing compressed permeate with any type of membrane are needed.

\section{Cost}

System construction entails forming the membranes into modules which are then incorporated into a system. In LT-HSMs, the membrane module selling price at high volume is in the range of $\$ 30$ to $300 / \mathrm{m}^{2}$ for present technology and projected to be $\$ 6$ to $15 / \mathrm{m}^{2}$ for advanced membrane designs. These prices are 2-3 times the module production cost. The module production cost is $10-25 \%$ of the total system cost. Whether a complete or partial system would be required for a particular $\mathrm{H}_{2}$ fueling station application will depend on the $\mathrm{H}_{2}$ generation technology it is mated with. The 2010 targets for Pd-based membranes are significantly higher, on the order of $\$ 1000 / \mathrm{m}^{2}$. At the target flux of $200 \mathrm{scfh} / \mathrm{ft}^{2}$, this translates to a capital cost of approximately $\$ 14,000$ for a membrane capable of producing $500 \mathrm{~kg}$ of $\mathrm{H}_{2}$ per day. Durability goals for these membranes are 100,000 hours. Such a system would have to be mated to a $\mathrm{H}_{2}$ storage subsystem. An on-demand $\mathrm{H}_{2}$ production system will require either an order of magnitude larger flux or lower cost.

\section{Technologies Available Now/By 2010}

The first large-scale applications of HSMs was for ammonia purge gas streams and adjusting $\mathrm{H}_{2}$ : $\mathrm{CO}$ ratio in syngas plants. These systems are comprised of LT-HSMs. Current suitability of LT-HSM technology for separating $\mathrm{O}_{2}-\mathrm{H}_{2}$ streams from photolytic generation 
schemes is unknown. However, the maturity of LT-HSM systems make them an attractive option to pursue as photolytic generation comes closer to reality.

Regulatory, crude quality, and economic factors are driving the increasing demand for increased $\mathrm{H}_{2}$ usage in refineries. Many of the gas streams in refineries are 30 to $80 \%$ hydrogen mixed with light hydrocarbons making them ideal for HSM systems. This, plus present applications are expected to create a \$90M market in 2010.

HT-HSMs are under development to separate $\mathrm{H}_{2}$ generated during combustion of natural gas, coal, and other fossil fuels from the product stream. In addition to potentially using HT-HSMs to reform natural gas on site, HT-HSMs are critical supporting technologies for next generation power systems under development in DOE's Vision 21, Clean Coal, and FutureGen efforts. The $\mathrm{H}_{2}$-depleted residue gas is then directed to units that separate and sequester $\mathrm{CO}_{2}, \mathrm{CO}$, and particulates. The combined driving forces of refinery and next generation power system applications creates a high probability that Pd-based HT-HSMs will be available by 2010 to separate $\mathrm{H}_{2}$ generated by both on-site and centralized natural gas reforming, though a $\mathrm{H}_{2}$ storage system will likely also be required. It is likely that the cost of hydrogen produced by these systems could be competitive with gasoline by 2015 .

\section{Technologies Potentially Available in the 2015-2030}

The availability of dual membrane HT-HSM systems for direct $\mathrm{H}_{2}$ generation via natural gas reforming is plausible for the 2015 timeframe. Though the potential exists for ondemand systems, the high operating temperatures will likely make continuous production most economical, creating the necessity for a $\mathrm{H}_{2}$ storage subsystem.

Thermal water splitting systems will need to utilize HT-HSMs due to the use of corrosive materials, such as sulfuric acid, hydrohalic acids, and water, at high temperatures $\left(750-900^{\circ} \mathrm{C}\right)$. However, it appears a significant amount of materials development is needed to achieve durability requirements for this application.

\section{Delivery Options}

For hydrogen infrastructure options that involve central production (i.e., other than onsite production at the fueling station, which is also referred to as forecourt production), the hydrogen must be delivered to the station from the production plant. Therefore, hydrogen delivery technologies are considered as part of this hydrogen production and distribution evaluation. There are numerous cost tradeoffs in comparing centralized (reforming) hydrogen production with truck delivery to forecourt reforming production. We do not explicitly give a side-by-side comparison here, instead the reader is directed to the National Academies report: "The Hydrogen Economy: Opportunities, Costs, Barriers, and R\&D Needs," which is available on the DOE website for more detailed information.

Hydrogen can be delivered as a compressed gas or cryogenic liquid. The compressed gas can be transported in a pipeline or in pressure vessels, which are typically transported over highways in so-called tube trailers. Liquid hydrogen is routinely transported over 
highways in tank trucks, although rail or barge transportation is also feasible. Liquid hydrogen pipelines longer than a few tens of meters are impractical due to heat transfer and vaporization.

DOE HFCIT has an active hydrogen pipeline R\&D program. This research is investigating issues such as new pipeline technologies and costs, the feasibility of converting natural gas pipelines to hydrogen, and the possibility of pipeline transportation of hydrogen mixed with natural gas. While these technologies are promising with regard to potential future central plant hydrogen production and distribution scenarios, they will probably not be fielded before 2010. There are a few existing highly localized hydrogen pipelines connecting production plants to petroleum refineries. Under DOE and SCAQMD sponsorship, APCI plans to install a hydrogen fueling station supplied by their pipeline in the Torrance, California area. However, there are very few of these existing hydrogen pipelines, and so we have not considered them to be a general hydrogen delivery option. Similarly, we categorize purpose-built hydrogen fueling station supply pipelines as a post-2010 option.

For Phase I, we consider three hydrogen delivery options: tube trailers, cryogenic tank trucks, and mobile fueling units. Pertinent information regarding these options is listed in the accompanying table. More detailed information is availed in the listed references. Mobile hydrogen fueling stations are considered here because most (but not all) mobile fuelers are refilled at central production plants.

Hydrogen delivery is potentially an important element of the California Hydrogen Highway Blueprint for two reasons:

1. In the longer term, if central production of hydrogen emerges to be more attractive than distributed production (in terms of societal benefits and economics), then delivery from the production plant to the fueling station is obviously required.

2. In the very near term, an excess supply of merchant hydrogen is available from existing hydrogen plants in California. Therefore, tube trailer or tank truck delivery, or use of mobile fueling units, may provide a low initial-cost option for providing fuel for hydrogen vehicles while other options with better societal benefits and life-cycle costs are being developed.

As indicated in the table, tube trailers typically hold roughly $120,000 \mathrm{scf}$ ( $280 \mathrm{~kg})$ of hydrogen at 2,400 to 3,100 psi. Tube trailers are usually leased (with a refill and delivery charge) from industrial gas companies, but they can also be purchased. A station utilizing a tube trailer has both simplifications and special requirements. Obviously, no hydrogen production or purification equipment is needed. On the other hand, a large area is needed for a truck to exchange the trailers. Also, in order to utilize a substantial fraction of the trailer capacity, a compressor and downstream pressure vessel cascade or buffer is needed. As a practical matter, because commonly used reciprocating compressors operate with a relatively inflexible pressure ratio, a pressure regulator is usually used between the trailer and compressor, which decreases efficiency and increases costs. On the other hand, a smaller 
pressure vessel cascade can be used compared to an equivalent-capacity onsite production station.

Tube trailers use DOT pressure vessels, and some jurisdictions prefer or require ASME pressure vessels for permanent installations. This may lead to permitting challenges if tube trailers are parked for long periods at hydrogen fueling stations used by the general public.

Cryogenic tank trucks hold from 10,000 to 17,000 gallons (approximately 2,600 to $4,400 \mathrm{~kg}$ ) of hydrogen, as indicated in the table. The tanks are vacuum-jacketed to provide the needed thermal insulation, an their construction conforms with DOT regulations. Cryogenic tank trucks deliver liquid hydrogen into a cryogenic tank at the fueling station. The basic infrastructure is analogous to gasoline and diesel fuel delivery and storage.

Liquid hydrogen delivery and storage is best suited to fueling stations with substantial and regular throughput, because this minimizes or eliminates boil-off losses. Also, for these stations, a liquid pump can replace the gas compressor. This reduces capital and operating costs, and it enables high-rate $(\mathrm{kg} / \mathrm{min})$ hydrogen dispensing with minimal cascade or buffer gas storage capacity. The economics of liquid or gaseous hydrogen delivery improve when the station is near the hydrogen plant.

The term "mobile hydrogen fueling station" covers a variety of devices, including:

- A trailer consisting of a pressure vessel cascade, dispenser, controls, and safety equipment - The cascade must be refilled frequently and/or vehicles cannot be refueled to maximum pressures.

- A trailer consisting of pressure vessels, a compressor, a small downstream pressure vessel cascade, dispenser, controls, and safety equipment - This system can use most of the stored hydrogen, but it is more complex and expensive.

- A trailer consisting of a compressor, downstream cascade, dispenser, controls, and safety equipment - This trailer connects to a hydrogen supply such as a tube trailer or pack of bottles.

- A small trailer-mounted electrolyzer, purification equipment, compressor, cascade, dispenser, controls, and safety equipment - This trailer connects to electric and water service, and it does not need to be refilled at a central plant.

Details regarding these mobile fueler alternatives are provided in the listed references. Experience to date shows that permitting mobile fueler applications can be just as involved as permitting a permanent hydrogen fueling station installation. However, mobile hydrogen fuelers may be a low-cost near-term option for providing temporary refueling capabilities, for hydrogen vehicles in California. 


\begin{tabular}{|c|c|c|c|c|c|}
\hline Delivery Option & $\begin{array}{l}\text { Development } \\
\text { Status/Industry } \\
\text { Readiness }\end{array}$ & $\begin{array}{l}\text { Technical } \\
\text { Barriers }\end{array}$ & $\begin{array}{l}\text { Economic } \\
\text { Barriers }\end{array}$ & $\begin{array}{l}\text { Environmental } \\
\text { Considerations }\end{array}$ & $\begin{array}{l}\text { Projected Cost in } \\
2010\end{array}$ \\
\hline $\begin{array}{l}\text { a) Liquid Hydrogen } \\
\text { Cryogenic Tank Trucks }\end{array}$ & $\begin{array}{l}\text { Liquid hydrogen tank } \\
\text { trucks (a tank semi- } \\
\text { trailer and a Class } 8 \\
\text { tractor) can transport } \\
\text { hydrogen from a } \\
\text { central production } \\
\text { plant to refueling } \\
\text { stations with liquid } \\
\text { hydrogen storage } \\
\text { tanks. This } \\
\text { infrastructure } \\
\text { scenario is analogous } \\
\text { to gasoline and diesel } \\
\text { fuel production and } \\
\text { distribution. The } \\
\text { capacity of current } \\
\text { liquid hydrogen } \\
\text { trucks ranges from } \\
10,000 \text { to } 17,000 \\
\text { gallons (Aprox. } 2,600 \\
\text { to } 4,400 \text { kg). Liquid } \\
\text { hydrogen is stored at } \\
\text { approximately } \\
-420^{\circ} \mathrm{F} \text { in a vacuum- } \\
\text { jacketed tank. }\end{array}$ & $\begin{array}{l}\text { Highway } \\
\text { transportation of } \\
\text { liquid hydrogen in } \\
\text { tank trucks is an } \\
\text { established } \\
\text { commercial } \\
\text { technology. There are } \\
\text { no technical barriers } \\
\text { and no R\&D } \\
\text { investment is } \\
\text { required. Trucks and } \\
\text { their operation are } \\
\text { regulated by DOT } \\
\text { and state codes. Their } \\
\text { safety record is } \\
\text { excellent. Liquid } \\
\text { hydrogen delivery is } \\
\text { appropriate only to } \\
\text { stations that store } \\
\text { liquid hydrogen, and } \\
\text { these stations are not } \\
\text { well suited to } \\
\text { applications with } \\
\text { lengthy idle periods } \\
\text { (due to product boil- } \\
\text { off loss). }\end{array}$ & $\begin{array}{l}\text { Currently, liquid } \\
\text { hydrogen tank trucks } \\
\text { are owned and } \\
\text { operated by central- } \\
\text { plant hydrogen } \\
\text { producers. There is } \\
\text { no initial capital } \\
\text { investment required. } \\
\text { Hydrogen purchase } \\
\text { contracts can be per } \\
\text { delivered kg. } \\
\text { Alternatively, liquid } \\
\text { hydrogen delivery } \\
\text { costs can be } \\
\text { estimated as } \$ 0.001 \\
\text { to } 0.003 \text { per kg-mile } \\
\text { (one way full truck } \\
\text { delivery). Note that } \\
\text { liquid delivery and } \\
\text { storage can reduce } \\
\text { station cost (pumps } \\
\text { are cheaper than } \\
\text { compressors and } \\
\text { minimal high- } \\
\text { pressure storage is } \\
\text { required) and enable } \\
\text { high dispensing rates. } \\
\text { Boil off losses must } \\
\text { be minimized to keep } \\
\text { costs acceptable. }\end{array}$ & $\begin{array}{l}\text { Liquid hydrogen } \\
\text { truck delivery } \\
\text { requires central plant } \\
\text { production and } \\
\text { liquefaction. Current } \\
\text { central plant } \\
\text { production is via } \\
\text { SMR, which } \\
\text { consumes natural gas } \\
\text { and emits substantial } \\
\text { greenhouse gas and } \\
\text { some criteria } \\
\text { pollutants. Current } \\
\text { liquefiers have } \\
\text { motor-driven } \\
\text { compressors, and the } \\
\text { associated grid- } \\
\text { electricity generation } \\
\text { emissions and } \\
\text { resource } \\
\text { consumption, } \\
\text { although these are } \\
\text { lower than those } \\
\text { associated with } \\
\text { electrolysis. The } \\
\text { diesel truck also } \\
\text { produces NO }, \text { PM, } \\
\text { and greenhouse } \\
\text { gases. }\end{array}$ & $\begin{array}{l}\text { A } 15,000 \text { gallon } \\
\text { liquid hydrogen } \\
\text { cryogenic trailer } \\
\text { costs approximately } \\
\$ 500 \mathrm{k} \text {. Liquid } \\
\text { hydrogen tank trucks } \\
\text { are a mature } \\
\text { technology, and } \\
\text { significant cost } \\
\text { reductions associated } \\
\text { with technology } \\
\text { improvements are } \\
\text { unlikely. Minor } \\
\text { economies of scale } \\
\text { may be realized if } \\
\text { more tank trucks are } \\
\text { built and operated. } \\
\text { DOE plans R\&D to } \\
\text { increase hydrogen } \\
\text { liquefaction } \\
\text { efficiency and hence } \\
\text { reduce cost. }\end{array}$ \\
\hline
\end{tabular}




\begin{tabular}{|c|c|c|c|c|c|}
\hline $\begin{array}{l}\text { b) Compressed hydrogen } \\
\text { tube trailers }\end{array}$ & $\begin{array}{l}\text { Hydrogen can be } \\
\text { transported from a } \\
\text { central production } \\
\text { plant and stored at a } \\
\text { fueling station site in } \\
\text { compressed hydrogen } \\
\text { tube trailers. A tube } \\
\text { trailer consists of a } \\
\text { pack of connected } \\
\text { cylinders mounted on } \\
\text { a semi-trailer that is } \\
\text { transported by a } \\
\text { tractor. Tube trailers } \\
\text { are typically } \\
\text { exchanged at the } \\
\text { customer's site. Tube } \\
\text { trailers have different } \\
\text { capacities, but } \\
\text { 120,000 scf (280kg) } \\
\text { at } 2,400 \text { to } 3,100 \text { psi } \\
\text { is typical. DOT } \\
\text { regulations apply to } \\
\text { tube trailers traveling } \\
\text { on highways, but } \\
\text { state or local } \\
\text { regulations may } \\
\text { apply to tube trailers } \\
\text { installed at stations. }\end{array}$ & $\begin{array}{l}\text { Highway } \\
\text { transportation of } \\
\text { compressed hydrogen } \\
\text { in tube trailers is an } \\
\text { established } \\
\text { commercial } \\
\text { technology. There are } \\
\text { no technical barriers } \\
\text { and no R\&D } \\
\text { investment is } \\
\text { required. Their safety } \\
\text { record is excellent. } \\
\text { Hydrogen may be } \\
\text { delivered to and } \\
\text { stored at fueling } \\
\text { stations designed to } \\
\text { accept hydrogen from } \\
\text { tube trail trailers. A } \\
\text { compressor is needed } \\
\text { for efficient use of } \\
\text { the hydrogen in the } \\
\text { tube trailer ( } 80-90 \% \text { ). } \\
\text { Most compressors } \\
\text { need a constant } \\
\text { suction pressure, } \\
\text { which requires a } \\
\text { pressure regulator } \\
\text { between the tube } \\
\text { trailer and } \\
\text { compressor. }\end{array}$ & $\begin{array}{l}\text { A tractor transporting } \\
\text { a tube trailer will } \\
\text { consume energy } \\
\text { equivalent to all the } \\
\text { energy in the tube } \\
\text { trailer if the delivery } \\
\text { is longer than roughly } \\
500 \text { miles. Therefore, } \\
\text { tube trailer delivery is } \\
\text { not an economically } \\
\text { viable long-term } \\
\text { strategy if the station } \\
\text { is not very near to the } \\
\text { production plant. } \\
\text { However, tube } \\
\text { trailers can be leased, } \\
\text { and therefore this } \\
\text { option may be } \\
\text { attractive for initial or } \\
\text { temporary } \\
\text { applications where } \\
\text { initial capital costs } \\
\text { are more important } \\
\text { than life cycle costs. }\end{array}$ & $\begin{array}{l}\text { Tube trailer hydrogen } \\
\text { delivery requires } \\
\text { central plant } \\
\text { production and } \\
\text { compression (usually } \\
\text { accomplished by } \\
\text { liquefaction, } \\
\text { pumping, and } \\
\text { vaporizing). Current } \\
\text { central plant } \\
\text { production is via } \\
\text { SMR, which } \\
\text { consumes natural gas } \\
\text { and emits substantial } \\
\text { greenhouse gas and } \\
\text { some criteria } \\
\text { pollutants. Current } \\
\text { liquefiers have } \\
\text { motor-driven } \\
\text { compressors, and the } \\
\text { associated grid- } \\
\text { electricity generation } \\
\text { emissions and } \\
\text { resource } \\
\text { consumption, } \\
\text { although these are } \\
\text { lower than those } \\
\text { associated with } \\
\text { electrolysis. The } \\
\text { diesel truck also } \\
\text { produces NO } \text {, PM, } \\
\text { and greenhouse } \\
\text { gases. }\end{array}$ & $\begin{array}{l}\text { A } 120,000 \text { scf } \\
\text { compressed hydrogen } \\
\text { tube trailer costs } \\
\text { approximately } \$ 140 \mathrm{k} \text {. } \\
\text { Compressed } \\
\text { hydrogen tube trailers } \\
\text { are a mature } \\
\text { technology, and } \\
\text { substantial cost } \\
\text { reductions associated } \\
\text { with technology } \\
\text { improvements are } \\
\text { unlikely. Minor } \\
\text { economies of scale } \\
\text { may be realized if } \\
\text { more tube trailers are } \\
\text { built and operated. } \\
\text { Also, ongoing DOE } \\
\text { compressed hydrogen } \\
\text { storage technology } \\
\text { R\&D programs } \\
\text { (which are targeted } \\
\text { primarily to on- } \\
\text { vehicle storage) may } \\
\text { be partially } \\
\text { applicable to tube } \\
\text { trailers. }\end{array}$ \\
\hline
\end{tabular}




\begin{tabular}{|c|c|c|c|c|c|}
\hline $\begin{array}{l}\text { c) Mobile hydrogen fueling } \\
\text { stations }\end{array}$ & $\begin{array}{l}\text { Various types of } \\
\text { mobile hydrogen } \\
\text { fueling units are } \\
\text { available. The } \\
\text { simplest is basically a } \\
\text { compressed hydrogen } \\
\text { pressure vessel } \\
\text { cascade plus } \\
\text { dispensing equipment } \\
\text { on wheels. A } \\
\text { compressor can be } \\
\text { added to increase the } \\
\text { usable hydrogen } \\
\text { fraction, but this } \\
\text { substantially } \\
\text { increases complexity } \\
\text { and cost. These } \\
\text { compressed hydrogen } \\
\text { mobile units are } \\
\text { refilled at a central } \\
\text { production plant or a } \\
\text { permanent fueling } \\
\text { station. Mobile } \\
\text { electrolyzer fueling } \\
\text { stations are also } \\
\text { available. These } \\
\text { require water and } \\
\text { substantial electric } \\
\text { service, but they do } \\
\text { not need to be refilled } \\
\text { at a production plant. }\end{array}$ & $\begin{array}{l}\text { While there are no } \\
\text { technical barriers to } \\
\text { mobile hydrogen } \\
\text { fueling units, they are } \\
\text { inefficient with } \\
\text { respect to \% usable } \\
\text { hydrogen (i.e., very } \\
\text { few cars can be } \\
\text { refueled to maximum } \\
\text { capacity) unless they } \\
\text { include a compressor } \\
\text { (which makes them } \\
\text { much more complex } \\
\text { and expensive). Also, } \\
\text { different codes and } \\
\text { regulations apply to } \\
\text { hydrogen } \\
\text { transportation and } \\
\text { stationary } \\
\text { applications, and this } \\
\text { creates permitting } \\
\text { problems. }\end{array}$ & $\begin{array}{l}\text { Mobile fuelers can be } \\
\text { leased. Therefore } \\
\text { they have low or zero } \\
\text { initial capital cost, } \\
\text { but they have } \\
\text { extremely high cost } \\
\text { measured as } \$ / \mathrm{kg} \text { for } \\
\text { long-term use. } \\
\text { Therefore, mobile } \\
\text { hydrogen fueling } \\
\text { units are used to } \\
\text { fulfill temporary } \\
\text { requirements such as } \\
\text { refueling before a } \\
\text { permanent station } \\
\text { installation is } \\
\text { complete, limited- } \\
\text { time demonstrations, } \\
\text { and hydrogen vehicle } \\
\text { events that are not } \\
\text { near existing stations. }\end{array}$ & $\begin{array}{l}\text { The environmental } \\
\text { considerations } \\
\text { associated with } \\
\text { mobile hydrogen } \\
\text { fueling unit use is } \\
\text { similar to tube trailer } \\
\text { use (above), except } \\
\text { that it is worse } \\
\text { because more } \\
\text { highway travel is } \\
\text { required per kg of } \\
\text { hydrogen dispensed. }\end{array}$ & $\begin{array}{l}\text { Current lease rates } \\
\text { for a } 162 \mathrm{~kg}(120 \mathrm{~kg} \\
\text { usable), 5,000-psi } \\
\text { mobile hydrogen } \\
\text { fueling units are } \\
\text { significant. These } \\
\text { rates may decrease in } \\
\text { the future if usage } \\
\text { increases and mobile } \\
\text { hydrogen fueler } \\
\text { leasing becomes } \\
\text { more competitive. } \\
\text { Capital costs of } \\
\text { mobile hydrogen } \\
\text { fuelers may decrease } \\
\text { as a result of DOE } \\
\text { hydrogen storage } \\
\text { R\&D and/or } \\
\text { increased pressure } \\
\text { vessel production } \\
\text { volumes. }\end{array}$ \\
\hline
\end{tabular}




\section{$\underline{\text { Recommendations }}$}

There are a number of important goals we want to achieve by developing hydrogen production and delivery technologies for the California Hydrogen Highways. These are: increasing energy security through reductions in foreign oil imports; improvement of the environment; and to enhance U. S. and California economic competitiveness. It is fortuitous that the use of hydrogen as a fuel in transportation will allow us to accomplish all three goals. Indeed, the argument to move to a hydrogen economy has to be made both because of its energy security and beneficial environmental aspects. There are important economic benefits to be gained through the commercialization of the hydrogen production and delivery technologies discussed in this report. First, numerous jobs will be created in the hydrogen industry in California. Secondly, these technologies will be exportable, not only producing financial gains for companies doing business in California but also improving the environment beyond California's borders. We will approach the work outlined in this report in phases. Our general recommendations to be carried forward throughout the development of the hydrogen infrastructure are given below. These are followed by a discussion of specific recommendations for Phase I, II, and III.

\section{General Recommendations}

\section{$\underline{\text { Start Now with the Best Available Technology }}$}

For the purposes of developing the transitional CA H2 Net, the State should utilize those technologies for hydrogen production and delivery that are available today, or most likely to be commercially available in the 2005-2010 timeframe. These technologies are natural gas reforming, electrolysis, and centralized production from natural gas reforming with truck delivery. In specific locales (e.g., Torrance), delivery through pipeline will play a role. Mobile refuelers can also be utilized. The DOE 2015 dispensed hydrogen cost goals $(\$ 2.85 / \mathrm{kg}$ for electrolysis and $\$ 1.50 / \mathrm{kg}$ for steam methane reforming (SMR)) are unlikely to be met by 2010. Therefore, we should not anticipate that hydrogen will be able to compete with gasoline in terms of cost on a per-gallon energy equivalent basis. In addition, the use of hydrogen as a fuel does not necessarily help solve pollution or greenhouse gas inventory problems in the near term. Indeed, electrolysis using electricity from the grid and SMR are not emission-free technologies unless $\mathrm{CO}_{2}$ capture and sequestration are developed. Electrolysis from renewable resources (e.g., wind) is an emission-free process; however, this production pathway can only be utilized to a limited extent in the near-term.

\section{Build consumer Knowledge and Gain Acceptance of new Technologies}

Nearer-term consumer acceptance would need to be obtained based on demonstration of these technologies. One of the best ways to accomplish this is for consumers to personally experience the new technology via a ride on a transit bus, hands-on refueling, visit to Hydrogen Power Parks, or through other education and outreach activities planned under the various fleet demonstrations to be conducted in California through Industry/Government partnerships. 
Leverage the Synergy between the SCAQMD and DOE Demonstrations

Significant activities are planned for the next five years in the State of California. Explicit mechanisms should be put in place, such as have begun under the early stages of the EO implementation planning, to ensure the State gains full advantage from the separate efforts and vice versa.

Develop Hydrogen from Renewable Resources

In the time period beyond 2010 we anticipate that other technologies for hydrogen production will become technically viable, and could become economically viable. These "farther out" technologies include photobiological and photoelectrochemical, biofermentation, pyrolysis and gasification of biomass and coal, high temperature thermochemical, and catalytic membranes. The DOE is sponsoring research aimed at advancing these technologies. The State may also wish to sponsor R\&D in this area to explore any early opportunities to demonstrate and utilize hydrogen production from these pathways. In particular, centralized biomass gasification and wind-powered electrolysis can potentially have a larger impact in specific regions of California during the time period between now and 2010 .

\section{Promote the Use of Hydrogen in Non-Transportation Applications}

Hydrogen production technology development can be advanced through expanded societal use of hydrogen. This will enhance the case for a market for hydrogen leading to increased private sector investment. The use of hydrogen as an energy storage medium and in fuels cells for stationary power should be promoted.

\section{Approach the Transition in Phases}

The State of California can accelerate the development of hydrogen production and delivery technology options within our borders. Three phases of activities are envisioned: Phase I (now-2010), Phase II (2010-2015), and Phase III (beyond 2015). Some specific recommendations for these time periods are given below. These programs should be guided by an ongoing and balanced assessment of hydrogen vs. other alternatives to achieve California's emissions, economic, and business climate goals.

\section{Specific Recommendations for Phase I, II, and III}

Phase I (now-2010): The Early Transition Period-Demonstrations, Technology Evaluation and Advancement, and Collaboration with Federal Programs

State funding should be provided for collaborative demonstration production projects involving private industry, universities, and California national laboratories. These demonstration projects should be done in collaboration/coordination with the existing and planned DOE infrastructure and fleet demonstration projects to best leverage resources. Obviously, emphasis should be given to co-locating distributed hydrogen production 
demonstration technology at sites where FCV and hydrogen ICEV demonstrations/fleets are to be placed. Demonstration of reduced hydrogen costs and scalability for SMR and electrolysis should be priorities. In the early transition years, distributed production facilities with capacities of 50-250 kg hydrogen per day are the target. Emphasis should be give on the development of prototype designs for distributed production that can be commercialized in the following years.

1. In coordination with federal funding, utilize PIER funding for fundamental and applied R\&D at California national laboratories and universities. Again, this work should be coordinated with the DOE program and used to fund promising technologies that might be under funded due to earmarking of the DOE budget or other constraints. The work should be focused on technologies that can exploit resources available in California. The major part of this funding should be directed towards technology development that could have an impact in the next 57 years. That is, additional funding should be provided for the development of those distributed production technologies that show current promise for ultimate wide scale deployment. This implies mass production and commercialization of units that can produce hydrogen at costs meeting or approaching DOE targets. Specific technologies include fuel reforming and electrolysis. In the area of advanced electrolysis, specific emphasis should concentrate on increasing system efficiency, lower cost materials and components, high pressure operation, and improved materials and system durability and reliability. Integration of electrolysis systems with wind and solar should also be addressed. Because they offer the promise of highest efficiency, the development of solid oxide electrolyzers (SOEs) should receive concentration

In the area of fuels reforming (specifically SMR), emphasis should again be directed towards solving technical hurdles that will allow cost reductions and improve systems reliability and durability. Specifically, improvements in reactor materials and development of lower cost, higher activity catalysts are important. Demonstration of scalability (to smaller size systems in the $50-250 \mathrm{~kg} /$ day range) should also be given attention. Co-production of hydrogen and electricity, as a way of reducing overall hydrogen costs, should be considered and further developed for applications where this option is economically justified.

Support should also be provided, albeit at less concentrated levels, for the development of the "farther out" production technologies. These technologies are not expected to play a significant role in hydrogen production until well after 2010. They include photobiological and photoelectrochemical, biofermentation, pyrolysis and gasification of biomass (particularly the smaller-scale distributed option) and coal, high temperature thermochemical, and catalytic membranes. Fundamental research on photobiological hydrogen production would make use the outstanding bioengineering centers available in California universities and national labs. There are many groups within California investigating photoelectrochemical hydrogen research. The primary goal of work in these areas should be to attack the technical hurdles to higher efficiency and lower cost for hydrogen production using these processes. 
2. Truck delivery to rural areas and smaller cities should be the principal method of providing hydrogen in the transitional period. Also in more remote rural areas, where natural gas pipelines are lacking, consideration should also be given to reforming of liquid fuels such as methanol and ethanol, as a truck distribution infrastructure for these energy carriers already exists.

3. Encouragement should be given to co-production of hydrogen (though electrolysis) at existing and planned wind and solar power sites. System integration and optimization issues need to be resolved and high efficiency under variable electrolyzer input conditions needs to be demonstrated.

4. While focusing on the development of Hydrogen Highways, the use of hydrogen and fuel cells should be promoted in stationary power production. The development of Hydrogen Power Parks should be encouraged with the public invited in as part of the public outreach/education campaign. These parks would not only be used for hydrogen refueling of vehicles but also for electricity generation in fuel cells. The Hydrogen Power Parks should function as demonstration sites for a variety of distributed hydrogen production technology options that show promise for economic and commercial viability.

5. The State should look for an early site to demonstrate the biomass production route for hydrogen, as well as ethanol and methanol from which hydrogen can be derived, given the strong synergy with resources in the State. Although the technology is further away, there may be a unique opportunity to begin the longer development curve.

6. The Hydrogen Highways Initiative should work with DOE in establishing appropriate safety, codes and standards for hydrogen production and use. Hydrogen purity requirements and refueling protocols are particular areas of interest.

Phase II (2010-2015): Implement Expanded Production Infrastructure-The Verge of Commercialization for FCVs and Expanded Stationary Power Uses

1. These years could see greatly expanded numbers of hydrogen ICEVs and FCVs (the latter still principally in fleet demonstrations) on California roads, advancing the case for mass production (commercialization) of FCVs. If these greatly increased numbers materialize, and consistent with hydrogen fuel demand, expanded distributed production infrastructure should accompany this increase. Depending on need, more refueling stations will need to be developed along highways and in rural areas utilizing the resources (feedstocks) most readily available in those areas, taking into consideration the economic factors involved. The use of fuel cells and hydrogen fuel in stationary power applications should also be expanded. 
2. Demonstrations of wider scalability for SMR and electrolysis should be done. For these technologies, demonstrate that it is possible to achieve DOE hydrogen cost targets of $\$ 1.50 / \mathrm{kg}$ for SMR and $\$ 2.85 / \mathrm{kg}$ for electrolysis. If achievement of these cost targets can be demonstrated and there is sufficient hydrogen demand for high station utilization, distributed station production capacities in the $250-1500 \mathrm{~kg} /$ day range should be demonstrated and deployed, particularly for SMR.

3. Advanced production technologies should continue to be developed through PIER program in conjunction with federal funding, and in partnership with the private sector. As technical hurdles are overcome and the case is made for commercialization, funding for SMR research should ramp down during this time period. Funding for advanced electrolysis research, particularly solid oxide electrolyzers (SOEs), should continue if there is a clear and economic commercialization pathway for this technology. There are more technical and economic hurdles for electrolysis using SOEs to overcome before the commercial case can be made for mass production. Early in this time period, the emphasis on SOEs should be directed towards the demonstration of prototypes with capacities in the $10-100 \mathrm{~kg} /$ day range. However, mass production of alkaline and PEM electrolyzer units in varying sizes can begin in this time period. Funding should be increased for the "farther out" production technologies of photobiological and photoelectrochemical, biofermentation, pyrolysis and gasification of biomass, high temperature thermochemical, and catalytic membranes. This funding should be contingent on successful research results indicating that it is possible to overcome scientific and engineering hurdles for these technologies so that the DOE 2015 hydrogen cost targets can be reached. During this time period, a down-selection process should be initiated to identify the most promising technologies in which to concentrate funding. This should be done in coordination with the DOE program, which will be investing significant resources into the development of all of these production methods.

4. Demonstrate commercial viability for co-production (electricity and hydrogen) Hydrogen Power Parks.

5. Optimize production and utilization of hydrogen as an energy carrier (energy storage medium) to facilitate the utilization of intermittent renewable sources of wind and solar. Compare economic viability with other means of integrating these intermittent resources, both with the grid and in stand-alone applications.

6. Poll public as to willingness to buy FCVs/H2 ICEVs and use hydrogen and use this information in establishing regional production options/station siting.

Phase III (beyond 2015): Full Implementation of the California Hydrogen Highways and the Extended Hydrogen Economy

1. In 2015 the automobile OEMs have stated that they will make decisions regarding mass production of FCVs. Hydrogen production will continue to rely heavily on fossil sources (e.g., SMR) although "carbon-free" hydrogen production options 
will continue to gain economic competitiveness. If the OEMs make a positive mass production decision and it is clear that the cars will be coming, the State should continue to encourage those advanced technologies that show promise for eventual commercialization in the years beyond 2015, concentrating funding in the down-selected technologies. Commercialization for these technologies should begin in the 2015-2030 timeframe. Production scenarios should rely on an optimized regional mix of technologies including renewable resources or nuclear, and fossil-based that provide both environmental and economic benefits. Both centralized and distributed production should be utilized. Analytical models should be utilized to optimize the electricity grid/hydrogen production capacities for maximum efficiency, lowest emissions, and lowest cost to consumer. With appropriate technology and if extremely strong customer support materializes, mostly "carbon-free" hydrogen production system could be achieved before 2050 .

2. While it is recognized that California Law currently prohibits the building of new nuclear power plants until the end-of-cycle waste disposal issue is resolved, once this issue is resolved and if there is continuing increasing strain on the electricity grid, nuclear options should again be considered. At that point, the recommendation would be to build and bring on-line co-production nuclear facilities for electricity and hydrogen. A goal would be to demonstrate thermochemical and electrolytic hydrogen production at a cost of less than $\$ 1.50 / \mathrm{kg}$.

3. Build hydrogen pipeline infrastructure within California for hydrogen delivery from centralized or sub-station production facilities. This should be complete by 2050. By then, the transition to a hydrogen economy in California can be accomplished. 


\section{Bibliography}

\section{General websites}

Access the following website for all DOE documents, including the Hydrogen Poster Plan, The Multiyear Research and Development Plan, The National Academy of Sciences Report, the 2004 Annual Program Review (covering projects in all areas of hydrogen production funded by DOE), and others

http://www.eere.energy.gov/hydrogenandfuelcells

This website provides access to the following information:

- DOE Multiyear Research and Development Plan

- The Hydrogen Poster Plan

- The Office of Hydrogen, Fuel Cells and Infrastructure Technologies Annual Program Review

- The National Research Council's (NRC) Report on the DOE's Hydrogen Program, "The Hydrogen Economy: Oportunities, Costs, Barriers, and R\&D Needs (2004), http://www.eere.energy.gov/hydrogenandfuelcells/advisory_panels.html

T. Lipman, et al, "An Integrated Hydrogen Vision for California," http://socrates.berkeley.edu/ rael/papers.html

\section{Costing Information}

http://www.eere.energy.gov/hydrogenandfuelcells/analysis/cost.html

Simbeck, D.; Chang, E. (2002), "Hydrogen Supply: Cost Estimate for Hydrogen Pathways-Scoping Analysis," January 22, 2002--July 22, 2002. 69 pp.; NREL Report No. SR-54032525 (Available from NREL web site, http://pix.nrel.gov:8020/BASIS/nich/www/public/SDF)

\section{Fueling Availability and Demand}

Ebeles, E., et al, "Supply and Demand Report for Future Hydrogen Use," CEC Hydrogen Fueling Infrastructure Study Task 6 report prepared by TIAX LLC and subcontractors, March, 2004 (Draft). 


\section{Fueling Station Design}

Powars, C., et al, "California Hydrogen Fueling Station Guidelines," CEC Hydrogen Fueling Infrastructure Study Task 3 report prepared by TIAX LLC and subcontractors, November, 2003 (Draft)

\section{Hydrogen Production via Coal Gasification with $\mathrm{CO}_{2}$ Capture and Sequestration}

S. Chalk, "Reviewing the First Year of the President's Hydrogen Fuel Initiative," DOE Hydrogen Program Review, Philadelphia, PA, May 24, 2004.

http://www.eere.energy.gov/hydrogenandfuelcells/pdfs/review04/1 steve chalk 04.pdf

P. Devlin, DOE Hydrogen Program EERE Production and Delivery, DOE Hydrogen Program Review, Philadelphia, PA, May 24, 2004.

http://www.eere.energy.gov/hydrogenandfuelcells/pdfs/review04/hpd_1_devlin.pdf

D. Gray and G. Tomlinson, "Hydrogen from Coal," MTR 2002-31, Mitretek Systems, Falls Church, VA, U.S. Department of Energy, Fossil Energy Programs: Hydrogen Program Plan, 2002.

United States Department of Energy, Office of Energy Efficiency and Renewable Energy, "Hydrogen Posture Plan: An Integrated Research, Development and Demonstration Plan," February 2004.

United States Department of Energy, Office of Fossil Energy, "Hydrogen from Coal Program: RD\&D Plan for 2004-2015," Draft for review, June 10, 2004.

United States Department of Energy, Office of Fossil Energy, "Future Gen Integrated Hydrogen, Electric Power Production and Carbon Sequestration Project”, March 2004

http://www.fe.doe.gov/programs/powersystems/futuregen/futuregen report march 04.pdf

United States Department of Energy, Office of Fossil Energy, Carbon Sequestration:

Technology Roadmap and Program Plan, April 2004.

http://www.fe.doe.gov/programs/sequestration/publications/programplans/2004/Sequestration Roadmap4-29-04.pdf

\section{Biomass Gasification}

S. Chalk, "Reviewing the First Year of the President's Hydrogen Fuel Initiative," DOE Hydrogen Program Review, Philadelphia, PA, May 24, 2004.

http://www.eere.energy.gov/hydrogenandfuelcells/pdfs/review04/1 steve chalk_04.pdf

P. Devlin, DOE Hydrogen Program EERE Production and Delivery, DOE Hydrogen Program Review, Philadelphia, PA, May 24, 2004.

http://www.eere.energy.gov/hydrogenandfuelcells/pdfs/review04/hpd_1_devlin.pdf 
T. Milne, C. Elam and R Evans, "Hydrogen from Biomass: State of the Art and Research Challenges, National Renewable Energy Laboratory," IEA/H2/TR-02/001, 2001.

http://www.eere.energy.gov/hydrogenandfuelcells/pdfs/hydrogen_biomass.pdf

National Academy of Engineering, The Hydrogen Economy: Opportunities, Costs, Barriers, and R\&D Needs, National Academies Press, Washington, DC (2004)

D. Simbeck and E. Chang 2002, "Hydrogen Supply: Cost Estimate for Hydrogen PathwaysScoping Analysis," NREL/SR-540-32525, November 2002.

P. Spath, J. Lane, M. Mann and W. Amos, "Update of Hydrogen from Biomass" NREL

Technical Report, NREL/MP-33112, 2000.

http://www.decisioneering.com/articles/download/biomass to hydrogen.pdf

United States Department of Energy, Office of Energy Efficiency and Renewable Energy, "Hydrogen Posture Plan: An Integrated Research, Development and Demonstration Plan," February 2004.

United States Department of Energy, Office of Energy Efficiency and Renewable Energy, "Hydrogen and Fuel Cells: Multiyear Program Plan. Section 3.1 Production" June 3, 2003. http://www.eere.energy.gov/hydrogenandfuelcells/mypp/pdfs/3.1_production.pdf

\section{High Temperature Thermo-chemical Water splitting}

Brown, L.C., G.E. Besenbruch, and K.R. Schultz (General Atomics), A.C. Marshall, S.K. Showalter, and P.S. Pickard (Sandia National Laboratories), and J.F. Funk (University of Kentucky), 2002: Nuclear production of hydrogen using thermochemical water-splitting cycles, paper prepared for presentation at the American Nuclear Society Meeting Embedded Topical "International Congress on Advanced Nuclear Power Plants (ICAPP)," Hollywood, Florida, 9-13 June; to be published in the Proceedings of ICAPP.

S. Chalk, "Reviewing the First Year of the President's Hydrogen Fuel Initiative," DOE Hydrogen Program Review, Philadelphia, PA, May 24, 2004.

http://www.eere.energy.gov/hydrogenandfuelcells/pdfs/review04/1_steve_chalk 04.pdf

P. Devlin, DOE Hydrogen Program EERE Production and Delivery, DOE Hydrogen Program Review, Philadelphia, PA, May 24, 2004.

http://www.eere.energy.gov/hydrogenandfuelcells/pdfs/review04/hpd_1_devlin.pdf

United States Department of Energy, Office of Energy Efficiency and Renewable Energy, "Hydrogen Posture Plan: An Integrated Research, Development and Demonstration Plan," February 2004.

United States Department of Energy, Office of Energy Efficiency and Renewable Energy, "Hydrogen and Fuel Cells: Multiyear Program Plan. Section 3.1 Production" June 3, 2003. http://www.eere.energy.gov/hydrogenandfuelcells/mypp/pdfs/3.1 production.pdf 
Yalçin, S., 1989: A review of nuclear hydrogen production, International Journal of Hydrogen Energy, 14 (8): 551-561. 


\section{Biological Hydrogen Production}

\begin{tabular}{|c|c|c|c|}
\hline Topic Area & Brief Content Description & URL & Additional Information \\
\hline \multirow[t]{6}{*}{ Photobiological } & $\begin{array}{l}\text { Photobiological hydrogen } \\
\text { production et al; reports on } \\
\text { hydrogen from a multitude of } \\
\text { renewable energy sources }\end{array}$ & $\begin{array}{l}\text { http://www.bellona.no/en/energy/report_3- } \\
\text { 1999/index.html }\end{array}$ & $\begin{array}{l}\text { Thomas Palm, Cato Buch, Bjørnar Kruse, Erik } \\
\text { Sauar, Report 3:1999 Green Heat and Power } \\
\text { Eco-effective Energy Solutions in the } 21^{\text {st }} \text { Century, } \\
\text { Published by Bellona Foundation } 1999\end{array}$ \\
\hline & $\begin{array}{l}\text { Photobiological hydrogen } \\
\text { production from acetic acid with } \\
\text { purple bacteria }\end{array}$ & $\begin{array}{l}\text { http://www.biohydrogen.nl/publicfiles/16_10 } \\
12 \text { 4_fotoh2\%20met\%20purper\%20wur.pdf }\end{array}$ & $\begin{array}{l}\text { Janssen et al, Photobiological Hydrogen } \\
\text { Production from Acetic Acid with Purple } \\
\text { Bacteria, Wageningen Univeristy }\end{array}$ \\
\hline & $\begin{array}{l}\text { Photobiological hydrogen } \\
\text { production Feasibility Study }\end{array}$ & $\begin{array}{l}\text { http://www.eere.energy.gov/hydrogenandfuel } \\
\text { cells/pdfs/26938iii.pdf }\end{array}$ & $\begin{array}{l}\text { Melis, Anastasios et al. Sustained Photobiological } \\
\text { Hydrogen Gas Production Upon Reversible } \\
\text { Inactivation of Oxygen Evolution in Green Alga, } \\
\text { Proceedings o the } 1000 \text { U.S. DOE Hydrogen } \\
\text { Program Review NREL/CP-S70-26938 }\end{array}$ \\
\hline & $\begin{array}{l}\text { Photobiological hydrogen } \\
\text { production Cost Analysis }\end{array}$ & http://www.nrel.gov/docs/fy04osti/35593.pdf & $\begin{array}{l}\text { Amos, Wade A., Updated Cost Analysis of } \\
\text { Photobiological Hydrogen Production from } \\
\text { Chlamydomonas reinhardtii Green Algae } \\
\text { Milestone Completion Report, NREL/MP-560- } \\
\text { 35593, National Renewable Energy Laboratory, } \\
\text { January } 2004\end{array}$ \\
\hline & $\begin{array}{l}\text { Survey's what's out there } \\
\text { including photobiological and } \\
\text { photochemical hydrogen } \\
\text { production }\end{array}$ & $\begin{array}{l}\text { http://www.nap.edu/openbook/0309091632/ht } \\
\text { ml/174.html }\end{array}$ & $\begin{array}{l}\text { The Hydrogen Economy: Opportunities, Costs, } \\
\text { Barriers, and R\&D Needs (2004) } \\
\text { National Academy of Engineering ( } \underline{\mathrm{NAE}}), \text { Board } \\
\text { on Energy and Environmental Systems (BEES) }\end{array}$ \\
\hline & $\begin{array}{l}\text { Papers by Melis on } \\
\text { photobiological hydrogen } \\
\text { production }\end{array}$ & $\begin{array}{l}\text { http://plantbio.berkeley.edu/faculty/faculty_pa } \\
\text { ges/Melis.html }\end{array}$ & $\begin{array}{l}\text { Melis A and Happe T (2001) Hydrogen } \\
\text { Production: Green Algae as a Source of Energy. } \\
\text { Plant Physiol. 127: 740-748 } \\
\text { Jin ES, Feth B and Melis A (2003) A mutant of } \\
\text { the green alga Dunaliella salina constitutively } \\
\text { accumulates zeaxanthin under all growth } \\
\text { conditions. Biotechnol. \& Bioeng. } 81: 115-124 .\end{array}$ \\
\hline
\end{tabular}




\begin{tabular}{|c|c|c|c|}
\hline & $\begin{array}{l}\text { Rhodobacter sphaeroides is a } \\
\text { photofermantative bacteria that } \\
\text { produces hydrogen in } \\
\text { defined media or in wastewater } \\
\text { upon illumination under argon } \\
\text { atmosphere. }\end{array}$ & $\begin{array}{l}\text { http://www.waterstof.org/20030725EHECO1- } \\
\text { 90.pdf }\end{array}$ & $\begin{array}{l}\text { THE RELATIONSHIP BETWEEN GROWTH } \\
\text { KINETICS AND HYDROGEN PRODUCTION BY } \\
\text { RHODOBACTER SPHAEROIDES } \\
\text { Ela Ero_lua, Altan Tabano_lu, Ufuk Gündüzb, } \\
\text { Meral Yücelb, Lemi Türkerc and_nci Ero_luaa } \\
\text { Department. of Chemical Engineering, Middle } \\
\text { East Technical University, 06531, Ankara, Turkey } \\
2002\end{array}$ \\
\hline & Photobiological hydrogen product & $\begin{array}{l}\text { http://www.qdio.ac.cn/english/meeting/Abstra } \\
\text { cts/SS1/Yasuo\%20ASADA.pdf } \\
\text { http://www.iea.org/dbtw- } \\
\text { wpd/textbase/work/2003/linking/asada.pdf }\end{array}$ & $\begin{array}{l}\text { Asada, Yasuo, Hydrogenase-mediated hydrogen } \\
\text { production by Cyanobacteria, College of Science } \\
\text { and Technology, Nihon University } \\
\text { By Same Author } \\
\text { Application of Microbial Photosynthesis to } \\
\text { Hydrogen Production }\end{array}$ \\
\hline & $\begin{array}{l}\text { Photobiological Hydrogen } \\
\text { Production }\end{array}$ & $\begin{array}{l}\text { http://catf.vizonscitec.com/index/175a5eadec8 } \\
\text { 8e8d088256b0c0060624d!opendocument }\end{array}$ & $\begin{array}{l}\text { Lindblad, P. } \\
\text { IEA H2 Agreement Task 15: Photobiological } \\
\text { Hydrogen Production - An International } \\
\text { Collaboration } \\
\text { Canadian Hydrogen Conference, June 17-20, } \\
\text { 2001, Victoria, BC, Canada } \\
\text { Date: } 06 / 01 / 2001\end{array}$ \\
\hline Photobiological & Renewable Hydrogen Production & $\begin{array}{l}\text { http://www.ornl.gov/ webworks/cppr/y2001/ } \\
\text { pres/109924_.pdf }\end{array}$ & $\begin{array}{l}\text { E. Greenbaum1, J. Woodward1, J. W. Lee1, B. R. } \\
\text { Evans1, H. M. O'Neill1, } \\
\text { N. I. Heyer1, J. F. Millsaps2, and B. Bruce2, } \\
\text { RENEWABLE HYDROGEN PRODUCTION } \\
\text { 1Oak Ridge National Laboratory } \\
\text { Chemical Technology Division } \\
\text { Oak Ridge, TN 37831-6194, } \\
\text { March 6-8, } 2001\end{array}$ \\
\hline $\begin{array}{l}\text { Photobiological/ } \\
\text { Photochemical } \\
\text { Hydrogen } \\
\text { production }\end{array}$ & $\begin{array}{l}\text { Photobiological / Photochemical } \\
\text { Hydrogen production }\end{array}$ & $\begin{array}{l}\text { http://images.energieportal24.de/dateien/dow } \\
\text { nloads/h2-production.pdf }\end{array}$ & $\begin{array}{l}\text { ADVANCED HYDROGEN } \\
\text { PRODUCTION TECHNOLOGIES, U.S. } \\
\text { DEPARTMENT OF ENERGY } \\
\text { Neil Rossmeissl, Hydrogen Program Manager }\end{array}$ \\
\hline
\end{tabular}




\begin{tabular}{|l|l|l|l|}
\hline $\begin{array}{l}\text { Photobiological/ } \\
\text { Photochemical }\end{array}$ & $\begin{array}{l}\text { Photoelectrochemical and } \\
\text { Photobiological Approaches To } \\
\text { Generation of Hydrogen from } \\
\text { Water }\end{array}$ & $\begin{array}{l}\text { http://abstract.confex.com/asm/ms2004/techpr } \\
\text { ogram/paper_4787.htm }\end{array}$ & $\begin{array}{l}\text { Deb, S. Photoelectrochemical and } \\
\text { Photobiological Approaches To Generation of } \\
\text { Hydrogen from Water, National Renewable } \\
\text { Energy Laboratory, Golden, CO, October 20, } \\
\text { 2004 }\end{array}$ \\
\hline Mutliple & $\begin{array}{l}\text { Biological, photobiological, } \\
\text { biomass hydrogen production }\end{array}$ & $\begin{array}{l}\text { http://refining.dis.anl.gov/oit/toc/h2proc_8.ht } \\
\mathrm{ml}\end{array}$ & $\begin{array}{l}\text { Ongoing DOE Research and Development } \\
\text { Relevant to the Refining Industry }\end{array}$ \\
\hline
\end{tabular}

